\title{
Role of the Host Genetic Susceptibility to 2009 Pandemic Influenza A H1N1
}

\author{
Gloria Pérez-Rubio ${ }^{1,+}{ }^{\mathbb{C}}$, Marco Antonio Ponce-Gallegos ${ }^{1,+}{ }^{\mathbb{D}}$, Bruno André Domínguez-Mazzocco ${ }^{1}$, \\ Jaime Ponce-Gallegos ${ }^{2}$, Román Alejandro García-Ramírez ${ }^{1}$ and Ramcés Falfán-Valencia ${ }^{1, *} \mathbb{D}$
}

1 HLA Laboratory, Instituto Nacional de Enfermedades Respiratorias Ismael Cosio Villegas, Mexico City 14080, Mexico; glofos@yahoo.com.mx (G.P.-R.); marcoapg@iner.gob.mx (M.A.P.-G.); bruno_andre_dm@hotmail.com (B.A.D.-M.); garra22noviembre@yahoo.com.mx (R.A.G.-R.)

2 High Speciality Cardiology Unit “Korazón", Puerta de Hierro Hospital, Tepic 63173, Nayarit, Mexico; jaimeponcegallegos@hotmail.com

* Correspondence: rfalfanv@iner.gob.mx; Tel.: +52-55-5487-1700 (ext. 5152)

+ These authors contributed equally to this work.

check for updates

Citation: Pérez-Rubio, G.; Ponce-Gallegos, M.A.; Domínguez-Mazzocco, B.A.; Ponce-Gallegos, J.; García-Ramírez, R.A.; Falfán-Valencia, R. Role of the Host Genetic Susceptibility to 2009 Pandemic Influenza A H1N1. Viruses 2021, 13, 344. https://doi.org/ $10.3390 /$ v13020344

Academic Editors: Angela L. Rasmussen and Juliet Morrison

Received: 23 December 2020

Accepted: 18 February 2021

Published: 22 February 2021

Publisher's Note: MDPI stays neutral with regard to jurisdictional claims in published maps and institutional affiliations.

Copyright: (c) 2021 by the authors. Licensee MDPI, Basel, Switzerland. This article is an open access article distributed under the terms and conditions of the Creative Commons Attribution (CC BY) license (https:/ / creativecommons.org/licenses/by/ $4.0 /)$.

\begin{abstract}
Influenza A virus (IAV) is the most common infectious agent in humans, and infects approximately $10-20 \%$ of the world's population, resulting in 3-5 million hospitalizations per year. A scientific literature search was performed using the PubMed database and the Medical Subject Headings (MeSH) "Influenza A H1N1" and "Genetic susceptibility". Due to the amount of information and evidence about genetic susceptibility generated from the studies carried out in the last influenza A H1N1 pandemic, studies published between January 2009 to May 2020 were considered; 119 papers were found. Several pathways are involved in the host defense against IAV infection (innate immune response, pro-inflammatory cytokines, chemokines, complement activation, and HLA molecules participating in viral antigen presentation). On the other hand, single nucleotide polymorphisms (SNPs) are a type of variation involving the change of a single base pair that can mean that encoded proteins do not carry out their functions properly, allowing higher viral replication and abnormal host response to infection, such as a cytokine storm. Some of the most studied SNPs associated with IAV infection genetic susceptibility are located in the FCGR2A, C1QBP, CD55, and RPAIN genes, affecting host immune responses through abnormal complement activation. Also, SNPs in IFITM3 (which participates in endosomes and lysosomes fusion) represent some of the most critical polymorphisms associated with IAV infection, suggesting an ineffective virus clearance. Regarding inflammatory response genes, single nucleotide variants in IL1B, TNF, LTA IL17A, IL8, IL6, IRAK2, PIK3CG, and HLA complex are associated with altered phenotype in pro-inflammatory molecules, participating in IAV infection and the severest form of the disease.
\end{abstract}

Keywords: influenza; inflammation; genetic susceptibility; polymorphisms; cytokine storm

\section{Introduction}

Influenza A virus (IAV), a single-stranded negative-sense RNA virus of the Orthomyxoviridae family, is the most common infectious agent in humans, causing significant morbidity and mortality in infants and the elderly every year [1,2]. Also, influenza infects approximately $10-20 \%$ of the world's population resulting in 3-5 million hospitalizations each year and an estimated 87.1 billion dollars in total annual economic burden in the United States alone [3]. Since 1918, humankind has experienced three influenza pandemics: the "Asian" influenza pandemic, in 1957, the "Hong Kong" influenza pandemic in 1968, and the 2009 so-named "swine flu" pandemic. Although mild compared to that of 1918, these pandemics highlight the constant threat that the influenza virus poses to human health [4].

In April 2009, the first influenza A H1N1 cases were registered in Mexico and associated with a surprising number of deaths [5], and it spread rapidly throughout the 
world [6]. Worldwide, estimates of the crude hospitalization fatality risk (HFR), defined as the probability of death among $\mathrm{H} 1 \mathrm{~N} 1 \mathrm{pdm} 09$ cases which required hospitalization for medical reasons, ranged from $0 \%$ to $52 \%$, with higher estimates from tertiary-care referral hospitals in countries with a lower gross domestic product. However, in wealthy countries, the estimation was $1 \%-3 \%$ in all settings [7].

\section{Bibliometric Analysis}

A scientific literature search was performed using the PubMed database; the Medical Subject Headings (MeSH) "Influenza A H1N1" AND "Genetic susceptibility" were used. Studies published between January 2009 to May 2020 were included due to the amount of information and evidence about genetic susceptibility generated from the studies carried out in the last influenza A H1N1 pandemic. The bibliometric analysis was performed using RISmed [8], and for the wordcloud creation with the keywords of articles included in this review, we used the wordcloud tool [9] in RStudio V 3.6.1 [10] following the workflow proposed by the libraries developer. Applying this criteria selection, 119 papers were identified. Figure 1 shows articles published with these MeSH by year in the period, as mentioned above, and journals where papers were published.

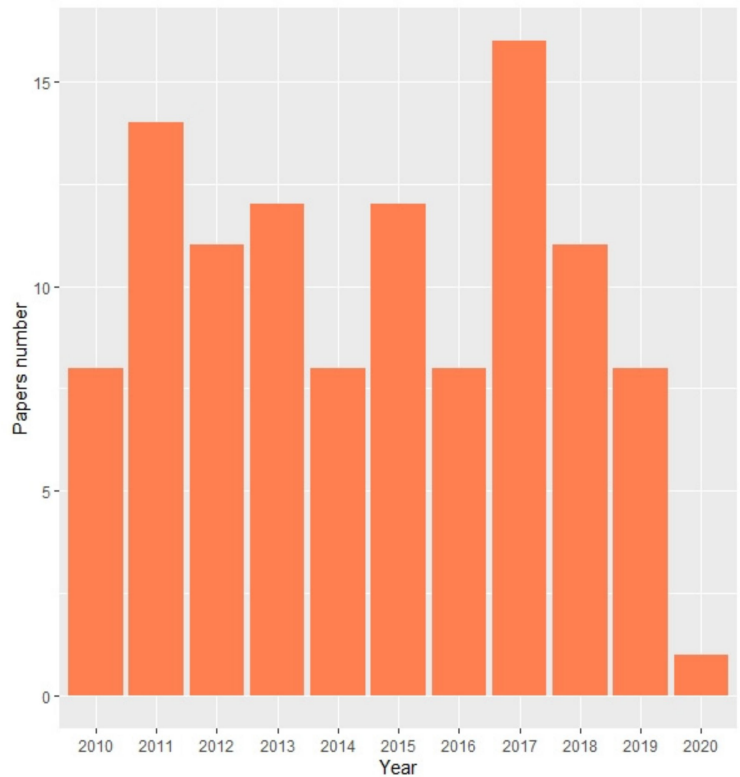

(a)

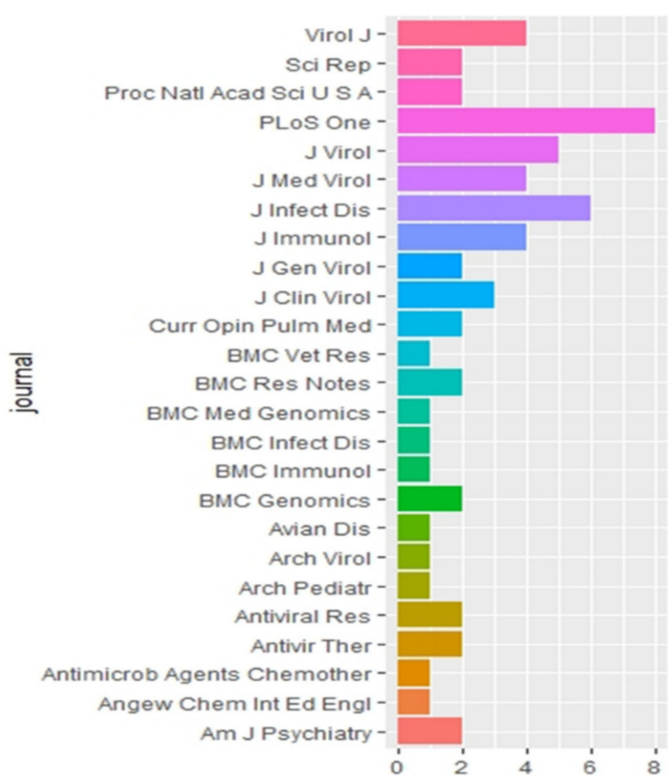

(b)

Figure 1. (a) Publications with the words "influenza A H1N1" and "genetic susceptibility" published between January 2009 to May 2020. (b) Top 25 journals where the 119 articles were published.

A wordcloud showing the main keywords terms in the bibliometric analysis is shown in Figure 2. 


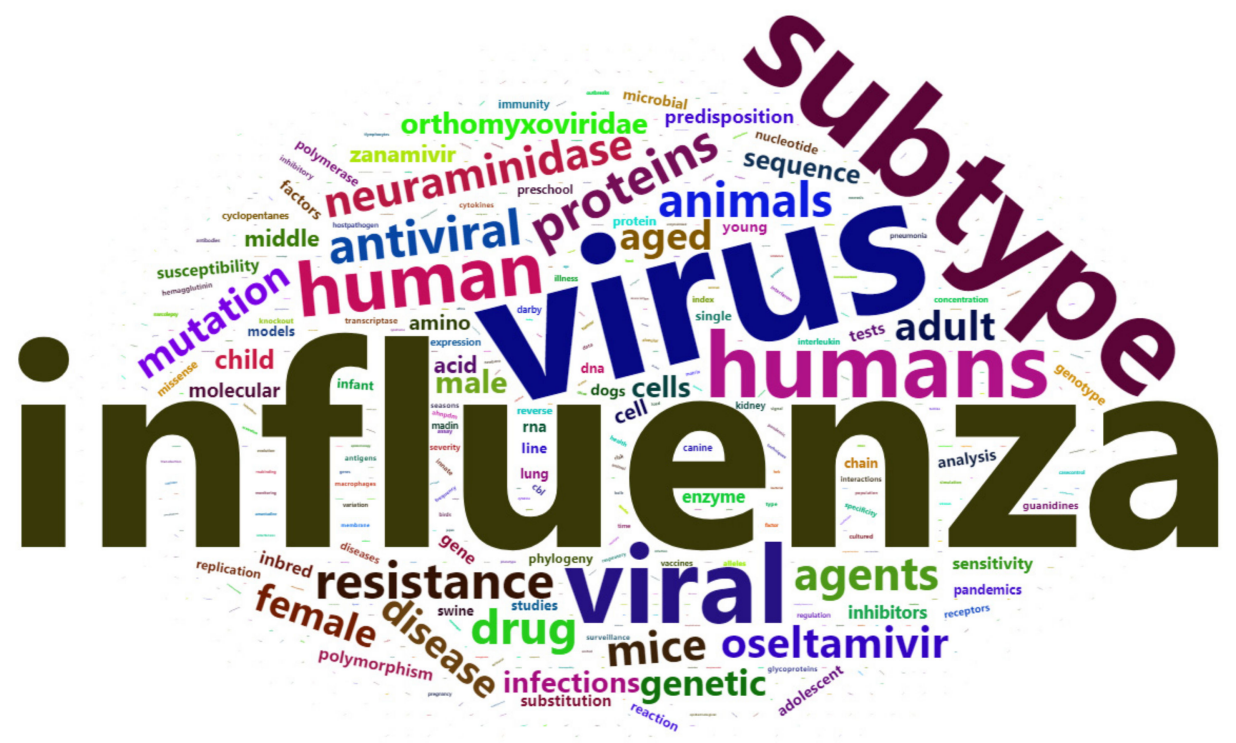

Figure 2. Depicting word cloud showing main keywords in the bibliometric analysis.

\section{Inflammatory Response and IFITM3 Role in Influenza A Virus Infection}

Through experimental and clinical studies, the systemic inflammatory dysregulation correlating with the disease's severity and progression has been identified as one of the most important pathogenic mechanisms in infection [11,12]. Cytokine secretion by infected cells is necessary for the initiation of the immune response that controls virus replication [13]; also, immunopathological mechanisms such as hypercytokinemia (also known as cytokine storm) generally contribute to the more severe evolution of the infection $[14,15]$.

A cytokine storm during viral infection is a prospective predictor of morbidity and mortality, yet the cellular sources remain undefined [16]. Critically ill patients who developed ARDS related to influenza A H1N1 virus infection had a slower decline in nasopharyngeal viral loads; had higher plasma levels of pro-inflammatory cytokines and chemokines; and were more likely to have bacterial coinfections, myocarditis, or viremia than patients in the survived-without-ARDS or the mild-disease groups. The hallmarks of the severity of disease were interleukin-(IL)-6, IL-8 and Tumor necrosis factor (TNF)- $\alpha$ [17]. The genes encoding these proteins are polymorphic, and specific alleles have been associated with susceptibility to different diseases, covering a broad spectrum of pathologies, from infectious to oncological, including pulmonary and systemic diseases [18-20].

These genes' extensive polymorphism could be associated with the high mortality rate during the A H1N1 influenza pandemic in Mexico and its high prevalence. According to Borja et al. 2012, a fourth wave observed in Mexico during 2011-2012 was not reported in other countries. Therefore, these differences could be explained by patterns of genetic susceptibility in Mexicans or vaccination coverage failures [21].

Elevated serum levels of IL-1 $\beta$ and IL- 6 have been identified as markers of severity in acute lung damage during influenza A H1N1 virus pdm09 infection; additionally, elevated levels of IL-1 $\beta$ are considered an early biomarker of the severity and progression of lung inflammation in patients who require mechanical ventilation and who do not respond to conventional antimicrobial treatments [22,23].

For example, the UK experienced two waves, one in spring-autumn 2009, followed by a more severe one in 2010-2011 [24,25], which was not seen in other European countries. These differences could be explained by geographic variations, previous immunity, control strategies, connectivity, public health, and for now, it remains a key for future research.

The defense mechanism that is provided by the innate immune system is the quintessential barrier, a specialized immune system in which different mucosa co-exist that fights the invasion of pathogens. The viral RNA is recognized as foreign by the different Pattern 
Recognition Receptors (PRRs) present in infected cells, which secrete type I interferons (IFNs), pro-inflammatory cytokines, eicosanoids, and chemokines [26]. Type I interferons, produced by macrophages, pneumocytes, dendritic cells, and plasmacytoid dendritic cells (pDCs), stimulate the expression of hundreds of collectively called IFN-stimulating genes (ISGs) in neighboring cells, which induce an antiviral state. Pro-inflammatory cytokines and eicosanoids lead to systemic and local inflammation, which results in fever and anorexia and instructs the adaptive system to respond to the influenza virus $[27,28]$.

The innate immune response comprises a system of mobile lines that encode different receptors inspecting the intracellular and extracellular compartments for signs of infection and highly conserved microbial motifs, also called pathogen-associated molecular patterns (PAMPs), which are molecular signatures of pathogens that facilitate induction of the host immune response; PAMPs activate cellular PRRs such as toll-like receptors (TLRs) to induce immunity [29]. Vast arrays of pathogens enable PRRs in the absence of PRR-specific PAMPs. It is thought that, during infection, cellular factors can activate PRRs and thus indirectly fulfill the function of PAMPs [30]. PRRs are classified into several families. The Toll-like receptor (TLR) family consists of more than ten members, which enable innate immune cells to respond to a variety of PAMPs [31]. TLR3, TLR7, TLR8, and TLR9 represent a TLR subfamily that recognizes viral nucleic acid and can induce type I IFN [32]. More recently, it has become apparent that viral RNA is also detected by members of the RIG-I-like RNA helicase (RLH) family, such as RIG-I and Mda5 [31-33]. TLR and RLH differ in their cellular localization, ligand specificity, and downstream signaling pathways, suggesting that host cells have multiple defense mechanisms against viral infection. Among ISGs, $2^{\prime}-5^{\prime}$-oligoadenylate synthetase (OAS) plays a critical role in antiviral immunity by synthesizing $2-5 \mathrm{As}$, which induces RNA degradation by activating a latent RNase (RNase L) pathway [34].

After infection, viral components are recognized by several PRRs that promote downstream cellular and humoral responses, including the cytokine storm [35], a term used for the first time in 2003 to describe an immune response to influenza infection about influenzaassociated encephalopathy [36]. The influenza-induced cytokine storm has been linked to aggressive pro-inflammatory responses and insufficient control of the anti-inflammatory responses [16]. Several experimental studies and clinical trials suggested that a cytokine storm correlates directly with widespread tissue damage and unfavorable prognosis of severe influenza [37]. Nevertheless, we have little understanding of the mechanisms that promote cytokine storms or why some individuals exhibit an excessive response to the virus that leads to hospitalization or death, while the majority of patients only develop a mild to moderate form of the disease, without this exaggerated inflammatory response.

Also, the innate immune system recognizes the influenza virus by members of some of the three different classes of PRRs. Increased cellular expression of TLR9, TLR8, TLR3, and TLR7 during influenza has been reported while TLR2 and TLR4 were suppressed [38]. TLR9 may be the critical receptor among pattern recognized receptors to recognize and bind to influenza A H1N1 virus [38].

The IL-1 receptor-associated kinases (IRAKs) are critical regulators of TLR/IL-1 signaling, critical regulators of mammalian inflammation, and innate immune response. The non-synonymous IRAK2 variant rs708035 (coding D431E) increases NF- $\mathrm{KB}$ activity and leads to more NF-kB-dependent pro-inflammatory expression cytokines compared with IRAK2 wild type [39].

Genetic studies in mice have determined a specific role for each of the ISGs, including the antiviral myxovirus resistance protein 1 (MX1), the interferon-inducing transmembrane protein (IFITM), and PKR, in limiting virus infection and its spread [38].

The myxovirus resistance (MX) genes are evolutionarily conserved in nearly all vertebrates. MX gene expression is induced by interferons type I or III, and the corresponding gene products can inhibit a wide range of viruses [38]. The MX1 is an interferon-induced GTPase that plays an essential role in the mammalian cell defense against influenza A viruses. Mouse MX1 interacts with the influenza ribonucleoprotein complexes (vRNPs) 
and can prevent the interaction between polymerase basic 2 (PB2) and the nucleoprotein (NP) of influenza A viruses [40]. Human MxA can suppress the replication of Orthomyxoviridae viruses (influenza and Thogoto), rhabdovirus (vesicular stomatitis virus), and hepadnavirus (hepatitis B virus), and mouse MX1 inhibits influenza and Thogoto virus replication [41].

IFITMs are a family of small proteins that comprises five members, including immunerelated IFITM1, 2, 3, 5, and 10, with IFITM3 being the most important in host defense against viral infections [42]. The human IFITM loci measure approximately $18 \mathrm{~kb}$ long and are located on chromosome 11. All of the IFITM genes contain two exons in their structure. The interferon-induced transmembrane protein 3 (IFITM3) gene is an endogenous immunerelated gene considered as a small ISGs, since it includes an interferon-stimulated response element (ISRE) in its promoter region, which promotes a robustly up-regulated expression of IFITM3 by the stimulus of all three types IFNs, resulting in a significant affinity of transcriptional factors, the most critical being POLR2A, MYC, ELF1, PHF8, CHD1, TAF1, REST, SIN3AK20, SIN3A, IRF1, STAT1, TBP, STAT3, STAT2, ZBTB7A, and CTCF [43-46].

IFITM3 is an essential antiviral factor that has been shown to restrict RNA viruses' replication, including IAV, the West Nile virus, and Dengue virus [47]. The mechanism of how IFITM3 regulates viral replication is not entirely understood. However, recent evidence suggests that IFITM3 is part of the endosomal compartments, preventing viral entry into the cytoplasm, preventing virus membrane fusion with cells, and inhibiting the fusion of infected cells (syncytialization) [48-50]. Essentially, IFITM3-deficient mice are more susceptible to influenza virus infection [47].

In this sense, studies in the IFITM3 knockout (KO) mouse model have demonstrated that gene suppression improves weight loss and mortality following influenza virus infections. Also, infected IFITM3 KO mice developed several cardiac disorders, such as aberrant cardiac electrical activity, including decreased heart rate and irregular, arrhythmic RR (interbeat) intervals. In contrast, WT mice exhibited a mild decrease in heart rate without irregular RR intervals. Additionally, these mice were accompanied by increased activation of fibrotic pathways and fibrotic lesions in the heart, suggesting a protective role of IFITM3 in the heart $[51,52]$.

\section{Genetic Variants and Influenza A H1N1 Virus Infection}

\subsection{Polymorphisms in the Complement System and Antibodies-Related Genes}

There is considerable variability in the disease severity resulting from infection with influenza viruses. There are primary determinants of this variability; among these are the virus's intrinsic pathogenicity, acquired host factors (such as immunity and comorbidities), and inherent host susceptibility. Whereas the viral genetic determinants of influenza severity and host immunity have been intensively studied, host genetic determinants are much less well studied. In 2009, the World Health Organization identified studies of the role of host genetic factors on susceptibility to severe influenza as a priority $[53,54]$.

Single nucleotide polymorphisms (SNPs) are genetic variants involving a particular base pair [55]. The genes coding for immune-response proteins are polymorphic, and specific alleles have been associated with susceptibility to respiratory diseases that cover a wide range of pathologies [18].

Reports have estimated an increase in the seasonal influenza-associated respiratory deaths each year worldwide, mostly affecting older individuals [56]. Promptly, an exploratory study was published, providing evidence that genetic factors played an essential role in determining the susceptibility of Mexican Mestizo individuals to the development of severe pneumonia in the first outbreak of influenza A H1N1 infection. The authors found significant associations of five SNPs (rs1801274, rs9856661, rs8070740, rs3786054, and rs3744714) located on chromosomes 1 and 3 with the development of severe pneumonia in patients with influenza A H1N1 virus infection [57]. Three of these SNPs occur in FCGR2A (Fc Fragment of IgG Receptor IIa) and C1QBP (Complement component $1 \mathrm{Q}$ subcomponentbinding protein), genes that may affect host immune responses to and/or replicate the 
A H1N1 influenza virus [57]. Immune complexes and complement activation have been implicated in the pathogenesis of the severe disease. Also, severe illness was found to be associated with high titers of low-avidity, non-protective anti-influenza antibodies, leading to immune complex deposition and complement activation in the respiratory tract [58]. Interestingly, the FCGR2A gene affects immune complexes' control, while C1QBP can activate the complement system.

The FCGR2A gene encodes the Fc $\gamma$ receptor IIA (Fc $\gamma$ RIIA), which binds immune complexes with high avidity [59]. The human FCGR2A gene in the 1q23 chromosome region encodes a member of the heterogeneous $\mathrm{FC}_{\mathrm{C}}$ fragment of the $\mathrm{IgG}$ receptor family of immune receptors. It contains a functional rs1801274 variation in exon 4, which leads to the amino acid alteration from histidine $(\mathrm{H})$ to arginine $(\mathrm{R})$ at position 131 of the Fc $\gamma$ RIIA protein [60]. The homozygous His131 genotype (A/A) was significantly enriched in patients with severe pneumonia compared with healthy A H1N1 exposed household contacts who did not develop respiratory illness [57]. The His131 allele of FCGR2A (Fc $\gamma$ RIIA-H131) has a higher affinity than the Arg131 allele (Fc $\gamma$ RIIA-R131) for all human IgG subclasses. The affinity of Fc $\gamma$ RIIA-R131 for IgG2 is notably reduced, and Fc $\gamma$ RIIa-H131 is the only human Fc $\gamma$ receptor that recognizes this IgG subclass efficiently [61]. Immunoglobulin engagement of activating-type Fc receptors such as Fc $\gamma$ RIIA induces multiple pro-inflammatory events, including immune cell degranulation and transcriptional activation of cytokine-encoding genes. Some Fc $\gamma$ RIIA alleles have been proven to modulate the phagocytes' ability to bind/internalize IgG-opsonised particles, with Fc $\gamma$ RIIA-H131 conferring higher phagocytic function [62].

On the other hand, SNPs in chromosome 17 have been associated with severe disease [57] and increased death risk [62]; the rs3786054, located in the C1QBP gene, encodes the protein $\mathrm{gC1qR}$, which was initially identified as a high-affinity receptor for $\mathrm{C} 1 \mathrm{q}$ [62] $\mathrm{C} 1 \mathrm{q}$ is the first subcomponent of the $\mathrm{C} 1$ complex of the classical pathway of complement activation [62], and gC1qR can activate this pathway [63]. gC1qR may also contribute to the activation of the classical pathway of Complement by the surface of activated platelets [63]. It suggests that the risk allele of $C 1 Q B P$ associated with severe A H1N1 disease is associated with increased complement activation [57].

\subsection{CD55 and RPAIN Polymorphisms}

In an initially small-scale genome-wide association study, with selection of Complement decay-accelerating factor (CD55) single-nucleotide polymorphisms in Chinese patients with severe to mild disease [64] and Sanger sequencing, the primary outcome analyzed was death [65]. The rs2564978 genotype TT carriers were significantly associated with a severe infection under a recessive model, after adjustment for clinical confounders [66] and hospitalization requirement [65]. Interestingly, in influenza A H1N1 pdm09 patients from Northern Greece, the rs2564978 TT genotype was associated with increased death risk too [62], and in Spain it was indirectly associated with influenza severity [67].

CD55 is a membrane-associated protein regulating complement activation by interfering with $\mathrm{C} 3 / \mathrm{C} 5$ convertases both in the classical and alternative pathways and naturally protects host cells from pathogens' damage. An allele-specific effect on CD55 expression was revealed and ascribed to a promoter indel variation in high linkage disequilibrium with rs2564978. The promoter variant with deletion exhibited significantly lower transcriptional activity. Also, the authors demonstrated that CD55 could protect respiratory epithelial cells from complement activation [66].

On the other hand, using a microarray with more than 50,000 genetic variants, Zúñiga et al. [57] found that RPAIN (Replication protein-A-interacting protein) gene, also known as $h R I P$ (human Rev-interacting protein), located in chromosome 17p13, is associated with influenza A H1N1 virus infection severity in a Mexican mestizo population. The authors hypothesize that the risk allele of hRIP/RPAIN (rs8070740) associated with severe A H1N1 disease is associated with increased influenza replication because it has been de- 
scribed that this protein interacts strongly with nuclear export protein (NEP), transferring the influenza RNAs from the nucleus of infected cells to the cytoplasm $[64,68,69]$.

\subsection{Genetic Variants in IFITM3 and Influenza A H1N1}

Several groups have investigated polymorphisms in the IFITM3 gene for association with IAV infection, disease severity, and clinical characteristics. Some genetic variations affecting the IFITM expression or function might contribute to viral pathogenesis [43].

Two SNPs (rs34481144 and rs12252) in IFITM3 have been widely studied and represent some of the most critical polymorphisms associated with IAV infection [70]. The rs34481144 A allele (located in the promoter region) enhances the binding of CTCF to the IFITM3 promoter, leading to a repressive effect on IFITM3 expression, causing a reduction in protein levels in endosomes and lysosomes. This allele has been associated with IAV infection in three different cohorts; in the FLU09 Cohort (participants met the clinical case definition of influenza virus infection at the enrollment time, or were asymptomatic household contacts of a participant with confirmed influenza infection), it was reported that there was a higher frequency of homozygosity of risk A allele in patients with severe illness than the mild cases, as well as an increased frequency of the A allele in the Cohort of Genentech challenge study (healthy volunteers between 18 to 45 years old and seronegative in hemagglutination inhibition assays against A H3N2 IAV) and the PICFlu cohort (a multicenter study of influenza critical illness in North American children admitted across 31 pediatric intensive care units) [46].

Conversely, David and co-workers [71] found a statistically significant protective effect of the rs34481144-A allele against severe influenza under the dominant model (OR = 0.26 ; $95 \%$ CI 0.07-0.97), which could be due to the minor allele's reduced frequency and the small sample size employed.

On the other hand, the most studied SNP associated with severe outcomes of IAV infection is rs12252, which is a non-synonymous variation in the first exon of IFITM3. The substitution of the $\mathrm{T}$ common allele for the alternative $\mathrm{C}$ allele might create an alternative splicing site and generate an N-terminal truncated variant of IFITM3 with 21 amino acid residues deletion [72]. The altered protein might be mostly translocated to the plasma membrane. Therefore, it cannot restrict viral infection by IAV and its full-length counterpart [50,73]. Figure 3 shows the proposed mechanism to explain how IFITM3 rs12252 participates in IAV infection.

This SNP has been associated with severe IAV infection in different populations. For example, Everitt et al. [72] reported that in diverse Caucasian populations, the $C$ allele of the rs12252 has a higher frequency in hospitalized patients with IAV infection than healthy controls. Besides, the CC genotype is found in $~ 70 \%$ of Chinese Han patients with severe IAV infection, compared with $25 \%$ in moderate disease [74]. Conversely, LópezRodríguez et al. [75] did not find any association with either alleles or genotypes of rs12252 and IAV infection in critically ill Spanish individuals and those with mild disease. Also, David et al. [71] did not find an association between rs12252/C allele with mild or severe IAV infection in a Portuguese population. Mills et al. [76] reported an association with the CC genotype of rs12252 and mild IAV infection, contrasting with previous studies where the association was founded with severely ill patients. These results could be related to a decreased $C$ allele frequency in European populations compared with Asian populations.

Wellington and co-workers [70] described that according to the 1000 genomes project [76], there are remarkable differences in rs34481144 and rs12252 in different populations, described in detail in Table 1.

Interestingly, minor allele frequency (MAF) of rs34481144 in the European population is higher than Asian populations, while in the opposite, MAF of rs12252 is much higher in Asian than European populations. Also, American and African populations are in the middle between European and Asian populations' frequency. 


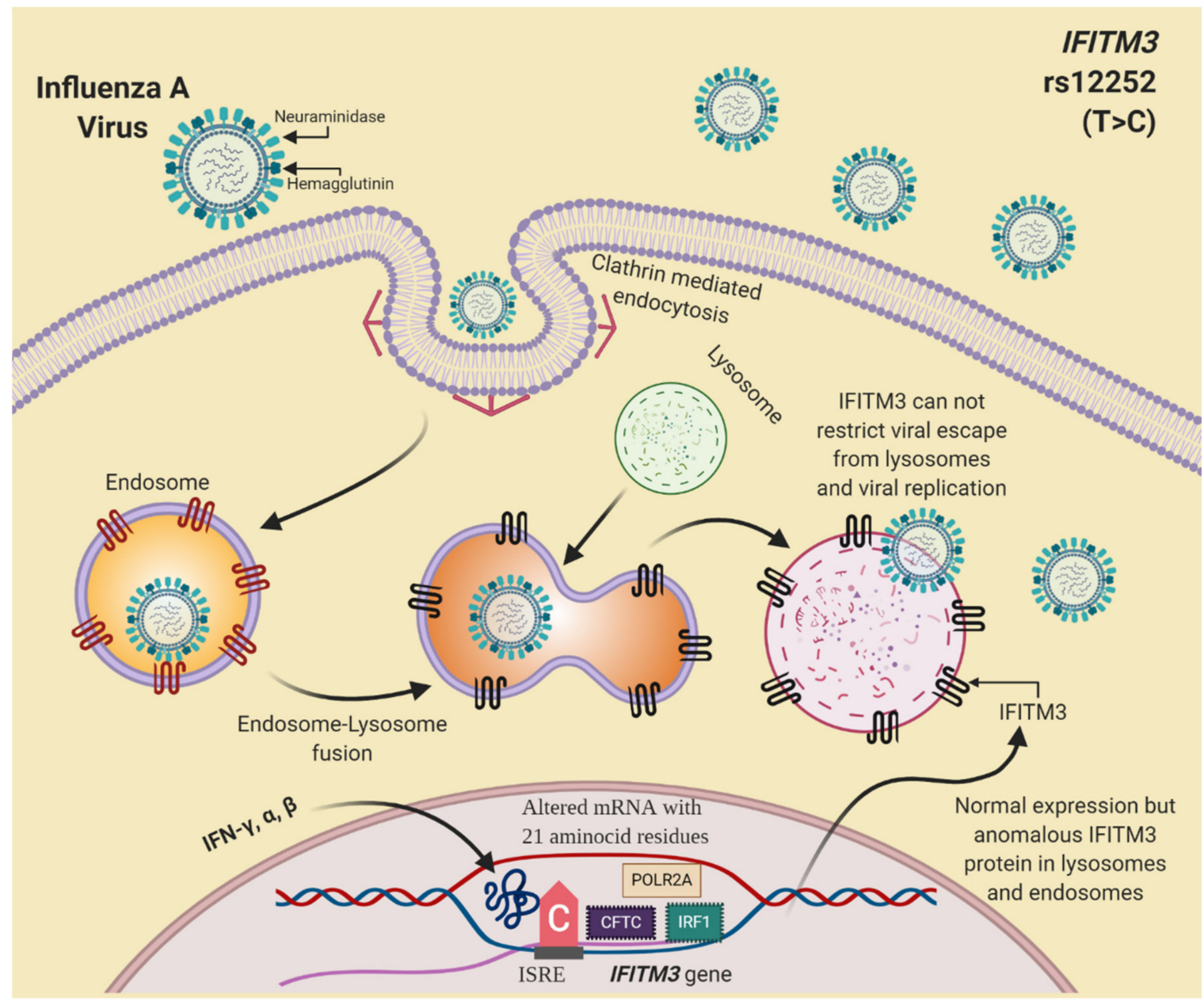

Figure 3. The proposed mechanism to explain IFITM3 rs12252 participation in influenza A virus (IAV) infection. Created with BioRender.com.

Table 1. Different IFITM3 single nucleotide polymorphism (SNP) allele distribution by populations.

\begin{tabular}{ccc}
\hline Population & rs34481144 G/A, (\%) & rs12252 T/C, (\%) \\
\hline African & $96 / 4$ & $74 / 26$ \\
American & $77 / 23$ & $82 / 18$ \\
East Asian & $99 / 1$ & $47 / 53$ \\
European & $54 / 46$ & $96 / 4$ \\
South Asian & $79 / 21$ & $85 / 15$ \\
All & $82 / 18$ & $76 / 24$ \\
\hline
\end{tabular}

In addition, David et al. [71] also described discrete difference in genotype frequencies from Central Africa (largely Angola, GG: 82\%, GA: 18\%) and Portugal (GG: 45\%, GA: 44\%, AA: 11\%), compared with African (GG: 90\%, GA: 10\%) and European (GG: 29\%, GA: 49\%, AA: 22\%) references from 1000 genomes. López-Jiménez et al. [77] described for the first time the allele and genotype frequencies of rs12252 from Western Mexico (four states: Nayarit, Jalisco, Colima, and Michoacán), where the frequencies, in general, were T: $82 \%$ and C: $18 \%$ for alleles, and TT: $67 \%$, TC: 30\%, CC: $3 \%$, which are very similar to the 1000 genomes project. 


\subsection{Inflammatory Response Genes and Influenza A H1N1}

Since the end of the 20th century, it has been described that variability in cytokine production between individuals may be due in part to genetic factors, especially the presence of polymorphisms in important regulatory regions, such as promoters $[12,13,78]$. It has been determined that the most important pathological mechanism in influenza A H1N1 infection is the systemic dysregulation of the inflammatory response, which is correlated with the illness severity and progression [79-82]. Besides, immunopathological mechanisms, such as hypercytokinemia, contribute to the severest evolution of the IAV infection [83-85]. The playing role of the polymorphisms of the genes encoding these cytokines in the disease's severity is not fully understood.

Cytokine production varies among individuals due to genetic factors, particularly polymorphisms in important regulatory regions such as promoters $[12,13,86]$. The role of polymorphisms in coding genes play in disease susceptibility and severity will be discussed.

Although it has been reported that some genes involved in inflammation are associated with respiratory diseases [87-92], investigations regarding genetic factors involved in the susceptibility and severity are scanty. Two primary examples in inflammatory response genes, where genetic variability is associated with an altered phenotype, are TNF- $\alpha$ and IL-1 $\beta$; both are pleiotropic modulators critical in regulating inflammation.

Since the initial discovery by Wilson et al. more than 20 years ago, using reporter genes under the control of the two allele TNF promoters, it has been shown that TNF2 (TNF-238/A allele) is a much more potent transcriptional activator than the TNF1 common allele (TNF-238/G allele) in a human B cell line [78], polymorphisms in the TNF promoter region have been the subject of multiples studies. Genetic variations in the TNF promoter region have been associated with a range of autoimmune [93-96], infectious [97-99], and oncological diseases [100-102].

In a case-control analysis in a Mexican mestizo population, the TNF rs361525 (AA genotype), rs1800750 (AA), and LTA (Lymphotoxin alpha) rs909253 (AG) were associated with a higher risk of infection by pandemic influenza A H1N1 [103,104]. Although mortality of the A H1N1 patients was higher than that of the influenza-like illness (ILI) patients, only LTA rs909253 AG genotype showed a limited statistically significant association with mortality, suggesting that being a carrier of heterozygous rs 909253 genotype in the LTA gene entails a poorer prognosis for this illness. Also, TNF rs1800629 GA and rs1800750 AA were associated with the severity of the clinical behavior. The first study demonstrated that the polymorphisms in genes related to the inflammatory response could be influencing the risk of infection and death by influenza A H1N1 virus [103]. A possible mechanism may be to form linkage disequilibrium between alleles, creating haplotypes that differentially affect cytokines and chemokines' expression and activity, thereby resulting in a severer clinical course for the infection. Late, in the same population, the TNF-238 (rs361525) GA genotype was associated with an increased risk of disease severity [104]. In contrast, the TNF-308 (rs1800629) AA genotype was associated with influenza A H1N1 infection in an Egyptian population [105], and the G allele with susceptibility to severe disease in another Mexican population [23].

Another well studied pro-inflammatory protein/gene is IL-1 $\beta / I L 1 B$; several studies have provided evidence about the association of IL1B-511 (rs16944) with gastric cancer [106], gastritis risk [107], including meta-analysis [108].

Studies in the Mexican population found the IL1B rs16944 AA genotype associated with a high amount of leukocytes [103]. In contrast, the rs3136558 CC genotype was associated with an increased risk, but rs16944 AG and rs3136558 TC were associated with a decreased risk of infection [104]. In an Iranian population, the rs16944 was associated with severe influenza disease [109]. In a Chinese population, the rs1143627 (IL1B) and rs17561 (IL1A) were found to be associated with susceptibility to A H1N1 pdm09 [110]. 
In humans, IL- 1 exists in two forms, IL- $1 \alpha$ (encoded by IL1A gene) and IL- $1 \beta$ (encoded by IL1B gene), both genes located on chromosome 2 [111,112]. IL- $1 \alpha$ and IL-1 $\beta$ are inflammatory cytokines that play essential roles in recruiting the immune and inflammatory cells and developing adaptive immune responses [113]. In bronchoalveolar lavage fluids and lung homogenates, there is an early increase in IL- 1 in temporal association with symptom presentation and lung pathology after infection with $\mathrm{A} / \mathrm{PR} / 8 / 34 \mathrm{H} 1 \mathrm{~N} 1$ or $\mathrm{A}$ H1N1 [22,114]. The rs17561 is a non-synonymous variant (Ala114Ser) in IL-1 $\alpha$ protein [115], suggesting that this genetic change may lead to a potential functional variation in host susceptibility to A H1N1 pdm09. It has also been related to high C-reactive protein levels, regulating the severe inflammatory response [116]. However, the exact mechanism needs to be further studied.

During IAV infection, the immune response is triggered by the influenza virus ion channel M2, an essential component for virus entry and replication, leading to the assembly of the inflammasome in macrophages and dendritic cells (DCs) $[117,118]$. Then, the inflammasome activation results in the cleavage of pro-IL- $1 \beta$ by caspase- 1 and produces the mature form of IL-1 $\beta$ [119]. IL- $1 \beta$ may act with IL- 6 to induce IFN- $\gamma$ production by T cells [120] and promote ROR $\gamma \mathrm{T}$ expression and Th-17 polarization of CD4 T cells [121]. The Th-17 effector cells produced IL-17 and facilitated the recruitment of neutrophils and inflammation [121].

In this sense, the IL6 rs1818879 (GA) heterozygous genotype has been associated with severe influenza A H1N1 virus infection. Compared with ILIs, patients with severe pA H1N1 infections exhibit increased serum IL-5 and IL-6 levels [104].

According to a genetic association study, the IL8 rs4073 AA genotype is considered a risk factor for influenza A H1N1 infected Egyptian patients [104], while in Mexican patients, it was associated with a higher value for partial arterial oxygen pressure $\left(\mathrm{PaO}_{2}\right) \mathrm{mmHg}$ (with $\mathrm{PaO}_{2}<60 \mathrm{mmHg}$ defined as a severe disease) [103]. Interestingly, the rs2275913 in the IL17A gene was associated with both risk of influenza A H1N1 infection and more severe disease [109]. In contrast, GG and AG genotypes were associated with seasonal influenza A/H3N2 risk of infection in the Iranian population [122].

As previously stated, the IAV causes a severe pulmonary disease characterized by intense leukocyte infiltration. Whereas the activation and recruitment of leukocytes are essential to control infection, excessive activation of neutrophils and macrophages might be harmful to the host $[123,124]$. Phosphoinositide-3 kinases (PI3Ks) are central signaling enzymes involved in cell growth, survival, and migration [125]. Class IB PI3K or phosphatidyl-inositol 3 kinase-gamma $(\mathrm{PI} 3 \mathrm{~K} \gamma)$, mainly expressed by leukocytes, is involved in cell migration during inflammation. The SNPs rs17847825 and rs2230460 (A and T alleles, respectively) in the PIK3CG gene were significantly associated with protection from severe disease using the recessive model in patients infected with influenza A H1N1 pdm09 [126]. Figure 4 shows a graphical summary of genetic polymorphisms and their participation in IAV infection. 


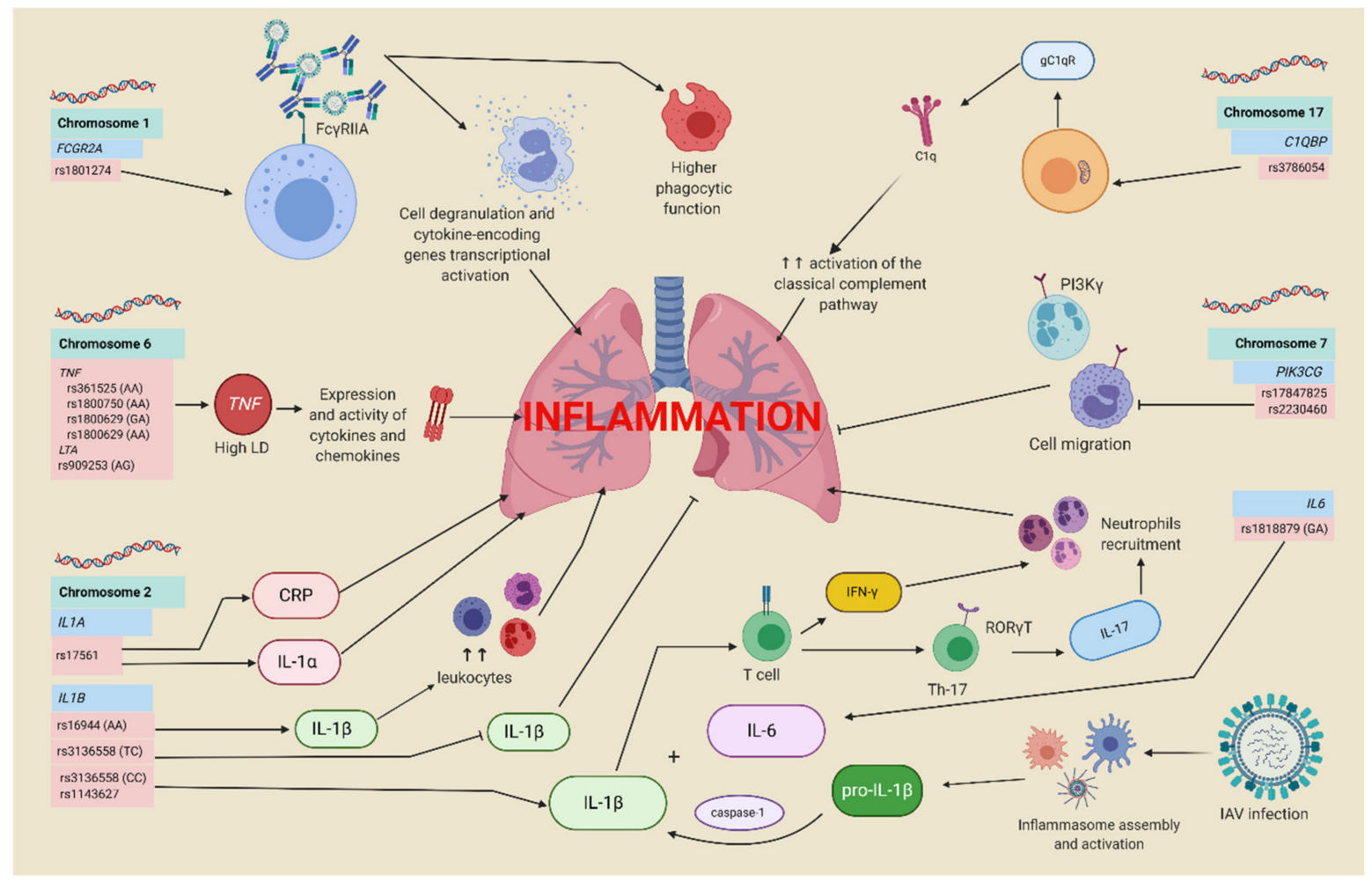

Figure 4. Graphical summary of genetic polymorphisms and their participation in IAV infection. Created with BioRender.com.

\subsection{HLA System Genetic Variants and Influenza A H1N1}

The human leukocyte antigen (HLA) super-locus is a genomic region in the chromosomal position 6p21 that encodes the six classical transplantation HLA genes and at least 132 protein-coding genes that have essential roles in the regulation of the immune system as well as some other fundamental molecular and cellular processes. This small segment of the human genome has been associated with more than 100 different diseases, including common diseases and various other autoimmune disorders [127]. The differential specificity, selectivity, and diversity of HLA directly reflects a fragile equilibrium between the interplay of molecular defense mechanisms against foreign antigens and autoimmunity acquired in the course of human evolution and migration. Selective combinations of HLA class I alleles exert different disease progression effects of infectious or autoimmune origin [128]. HLA class I is involved in both innate (NK cells) and cell-mediated (CD8+ cells) immune response, significantly contributing towards viral clearance and a decrease in the severity of influenza infection [129-132]. Cellular immune response to influenza viruses in adults is dominated by memory responses, as most individuals are repeatedly exposed to circulating influenza strains (either by natural infection or vaccination) throughout their lives. Seasonal changes in viral strains usually do not generate completely novel T-cell epitopes, so HLA class I or II-restricted epitopes from previous influenza seasons are present as identical or highly-homologous sequences in new seasonal influenza strains. However, in the case of a new H1N1 strain, influenza A H1N1 pdm09 was a reassortment of swine, human, and avian influenza A strains $[133,134]$.

The HLA genetic association studies focusing on the role of susceptibility to influenza A H1N1 are exceedingly scanty. Only two researches have documented specific HLA alleles associated with influenza A H1N1 virus infection.

In a Mexican-mestizo population, a lower frequency of $A * 24: 02: 01$ allele in patients compared to asymptomatic contacts was found [135], suggesting a possible protective effect. This result disaccords with a previous study where the A*24 serogroup (A24 family) correlates positively with severe A H1N1 infection and mortality [136]. Nevertheless, 
this information was acquired by employing database analysis of conserved proteomic regions-based experimental predictions of HLA binding affinity, showing that HLA alleles preferentially target conserved regions of viral proteins, phenomena known as HLA targeting efficiency [137]. The study did not consider HLA-restricted NK cell-mediated viral clearance, which may have introduced a certain degree of bias. The HLA-A*24 subtype is a potential ligand for KIR3DL1, rendering an inhibitory NK signal [138], probably reducing the immune system over-reactivity to influenza A H1N1 pdm09 virus, which is known to contribute to the significant pathobiology of the disease [139]. $A^{* 24: 02}$ is in linkage disequilibrium with $B * 39: 01$ [140], which possesses high targeting efficiency scores. $A^{*} 24$ comprises a large portion of the world population; this allele family is more common in some indigenous groups and constitutes more than half of the global population, especially in Asian countries and several Native American populations [141]. There is variability in the $\mathrm{A}^{*} 24$ frequencies in Mexican mestizos depending on the Amerindian contribution and the region studied [142]. In this study, only $8.33 \%$ of the patients had any allele of the

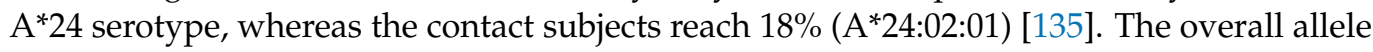
frequency of $A^{*} 24: 02$ in Mexican mestizos is $16.4 \%$ [142]. Recently, a cross-HLA allele T cell response against the influenza A virus peptides were detected among both HLA-A11(+) and HLA-A24(+) donors. Furthermore, cross-responses were found in the entire HLAA3 supertype population (including HLA-A11, -A31, -A33, and -A30). The cross-allele antigenic peptides within the peptide pool were identified and characterized, and the crystal structures of the major histocompatibility complex (MHC)-peptide complexes were determined. The subsequent HLA-A24-defined cross-allele peptides recognized by the HLA-A11(+) population were shown to bind to the HLA-A*1101 molecule slightly [143]. In a preliminary study, the HLA-A* 11 and HLA-B*35 alleles were found conferring susceptibility to influenza A (H1N1) in the Northeast India population pdm09 [144]. A*02 subtypes are considered a general protection factor against influenza A H1N1 infection [145].

The HLA dataset contains six $A^{*} 68$ alleles, and two belong to different supertypes: $A^{*} 68: 01$ to the $A 3$ supertype and $A^{*} 68: 02$ to the $A 2$ supertype. No association was found with $A^{*} 68: 02: 01$ to A H1N1/09 infection, while $A^{*} 68: 01: 01$, despite its low frequency $(<2 \%)$, was only present in patients [135]. This is in concordance with the HLA targeting efficiency study results showing that $A^{*} 68: 01$ subtypes correlate positively with A H1N1 pdm09 mortality rates but not $A^{*} 68: 02$ [136]. The potential impairment of HLA- $A^{*} 68: 01$-restricted CD8+ T cells to mount robust immune responses was recently investigated, demonstrating the immunodominance potential of influenza-specific CD8+ T cells presented by a risk HLA-A*68:01 molecule, and advocates for priming CD8+ T cell compartments in HLA$\mathrm{A}$ *68:01-expressing individuals for establishment of pre-existing protective memory $\mathrm{T}$ cell pools.

Higher frequencies of $B * 39: 06: 02$ and $B * 51: 01: 05$ were observed in subjects suffering from influenza A H1N1. Despite high targeting efficiency scores, B*39:06:02 (Bw6) allele frequency was higher in A H1N1 patients than asymptomatic contacts, which could be due to selective pressure exerted by certain KIR-HLA combinations favoring under-reactivity of NK cells. Interestingly, the allele B*39:06 has been observed in several Amerindian populations with a frequency of around $5 \%$ [140] and possesses a high targeting efficiency score [136]. In contrast, B*39:01:01, another Bw6 supertype, showed a protective effect; this observation may be due to strong linkage disequilibrium with $A^{*} 24: 02$ existing in Amerindian populations. A higher frequency of $B * 51: 01: 05$ was also found in influenza A H1N1 patients. Another allele, HLA-B*51:01:01, an ancestral allele of Amerindian origin [140], had low frequency in A H1N1/09 patients, suggesting a possible protective role. In contrast with the HLA-A alleles, the HLA-B alleles bind more efficiently with the A H1N1 viral proteins' conserved regions. Molecular subtypes of HLA-B*39 (B*39:01 and $B * 39: 06)$, common in Amerindian populations, are associated with severe disease forms [136], which may be a result of these alleles in linkage disequilibrium with another region within or close to the HLA locus. 
Despite its shallow frequency in the Mexican population, a high $C^{*} 03: 02: 01$ was observed in Mexican influenza A H1N1/09 patients [140]; however, this was not statistically significant after Bonferroni correction. On the other hand, $C^{*} 03: 03: 01, C^{*} 03: 04: 01$, and $C^{*}$ 07:01:01 showed low frequency in the influenza patients group. Compared to HLA-A or HLA-B, HLA-C is less polymorphic and presents a more restricted repertoire of peptides and low cell surface expression [146-148]. A proportionally higher frequency of KIR2DL1 C2- C1+ and KIR2DL3 C1+ was reported in ICU A H1N1/09 patients (indigenous and nonindigenous), relative to healthy controls [139].

A relatively low frequency of the $A^{*} 02: 01: 01-B * 35: 01: 01-C^{*} 04: 01: 01$ haplotype was observed among the A H1N1/09 patients. This specific HLA haplotype represents more than $2.5 \%$ in the control group and has been found only in Hispanic and Mexican populations $[140,142]$ with the resolution employed in this study. An increase in the frequency of $A^{*} 68: 01: 02-C^{*} 07: 02: 01$ haplotype in the patients' group was also observed, a relevant finding since linkage disequilibrium is very high in the region, rendering potential haplotypes and can potentially amplify the disease risk.

An analysis of the LIFT cohort [149] found that Indigenous Australians display a restricted and distinctive HLA profile confirming previous published serological studies [150]. Trough molecular HLA typing verified the predominant frequencies of HLA-A*02:01, 11:01, 24:02, 34:01 and HLA-B*13:01, 15:21, 40:01/02, 56:01/02. Such restriction in HLA diversity and HLA usage is likely to have arisen from an evolutionary bottleneck that established a small ancestral pool with limited HLA diversity. As HLA alleles' variability evolves rapidly, it is intriguing that there is a high degree of conservation in Indigenous Australians [149]. This could be partly explained by limited mixing with other populations, long-term adaptation to local pathogens, and minimal exposure to new pathogens that might drive selection and/or the emergence of new variants. Before European contact in the eighteenth century, limited or no influenza exposure may explain a low prevalence of protective HLA variants for influenza [149]. Also, serologically-defined HLA-A2-homozygous lymphocytes, in contrast to heterozygous lymphocytes, did not synthesize detectable influenza virus RNA or protein after exposure to the virus. HLA-A2-homozygous lymphocytes (including both homozygous and heterozygous donors) did internalize infectious viruses but were not susceptible to lysis by autologous virus-specific cytotoxic T lymphocytes ("fratricide"). A similar intrinsic resistance to influenza virus infection was observed with HLA-A1- and HLA-A11-homozygous lymphocytes and HLA-B-homozygous lymphocytes, suggesting that a significant proportion of individuals within a population that is characterized by common expression of HLA class I alleles may possess lymphocytes that are not susceptible to influenza virus infection and thus to mutual virus-specific lysis [151].

Besides, it has been recently described that an SNP (rs2071888/G allele and GG genotype) in TAPBP (TAP binding protein or Tapasin), a critical cofactor required for the assembly of HLA class I with exogenous peptides obtained by intracellular degradation through proteasome, is associated with a higher risk for Influenza A H1N1 virus infection in a Mexican mestizo population, suggesting a critical role of the antigen presentation process in the development of the disease [152].

Finally, the lack of a universal vaccine against all serotypes of influenza A viruses and the recent progress on $\mathrm{T}$ cell-related vaccines against influenza A virus illustrate HLA-restricted cytotoxic T lymphocytes' critical role in anti-influenza virus immunity. However, the diverse HLA alleles among humans complicates virus-specific cellular immunity research. Elucidation of cross-HLA allele T cell responses to influenza virus specificity requires further detailed work.

\section{Conclusions}

In recent years, several lines of evidence have determined that the role of host factors in genetic susceptibility to Influenza A Virus infection displays an essential part in the appropriate immune response to the virus, determining the outcome of infection. Numerous genes participate in diverse mechanisms against the viral response, such as 
pro-inflammatory pathways, complement activation, processing and antigen presentation, and intracellular control of viral replication; genetic variants in these genes could generate an abnormal function or decreased levels of the molecules, leading to higher viral replication and an exaggerated immune response to IAV infection. The evidence suggests that a variety of genetic variants can contribute to susceptibility to other influenza A strains (such as H3N2), not only A H1N1, since they share a similar structure, surface proteins, and genetic components that induce the same immune response. However, despite this amount of evidence, genetic susceptibility markers that are not linked to immunity have not been widely studied, probably because the efforts to study the molecular mechanisms are focused on elucidating the pathogenesis of IAV infection. So, this could be an essential field for future investigations.

Unfortunately, the evidence of the SNPs in the host genetic susceptibility to IAV is still inconsistent, and this can be partially explained by the differences in the genetic background of the populations around the world, especially in those that are considered as mestizo populations with a rich genetic variability, which is a product of the years of genetic recombination between ancestral Amerindian, Caucasian, African, and Asian populations. In this context, more collaborative research is required to provide a better understanding of the genetic determinants of the biological mechanisms of host susceptibility, which could result in early prevention, better diagnostic methods, and directed-therapy interventions at populations with a higher risk for developing a more severe form of the disease to offer a better prognosis in the future.

Funding: The allocated budget supports this work to research (RFV-HLA Laboratory) from the Instituto Nacional de Enfermedades Respiratorias Ismael Cosio Villegas (INER).

Institutional Review Board Statement: Not applicable.

Informed Consent Statement: Not applicable.

Data Availability Statement: No new data were created or analyzed in this study. Data sharing is not applicable in this article.

Acknowledgments: The authors wish to thank Instituto Nacional de Enfermedades Respiratorias Ismael Cosio Villegas for the facilities to carry out this Review.

Conflicts of Interest: The authors declare no conflict of interest.

\section{References}

1. Kim, H.W.; Brandt, C.D.; Arrobio, J.O.; Murphy, B.; Chanock, R.M.; Parrott, R.H. Influenza A and B virus infection in infants and young children during the years 1957-1976. Am. J. Epidemiol. 1979, 109, 464-479. [CrossRef]

2. Lipatov, A.S.; Govorkova, E.A.; Webby, R.J.; Ozaki, H.; Peiris, M.; Guan, Y.; Poon, L.; Webster, R.G. Influenza: Emergence and Control. J. Virol. 2004, 78, 8951-8959. [CrossRef]

3. Molinari, N.-A.M.; Ortega-Sanchez, I.R.; Messonnier, M.L.; Thompson, W.W.; Wortley, P.M.; Weintraub, E.; Bridges, C.B. The annual impact of seasonal influenza in the US: Measuring disease burden and costs. Vaccine 2007, 25, 5086-5096. [CrossRef]

4. Short, K.R.; Kedzierska, K.; Van De Sandt, C.E. Back to the Future: Lessons Learned From the 1918 Influenza Pandemic. Front. Cell. Infect. Microbiol. 2018, 8, 343. [CrossRef] [PubMed]

5. Echevarría-Zuno, S.; Mejía-Aranguré, J.M.; Mar-Obeso, A.J.; Grajales-Muñiz, C.; Robles-Pérez, E.; González-León, M.; OrtegaAlvarez, M.C.; Gonzalez-Bonilla, C.; Rascón-Pacheco, R.A.; Borja-Aburto, V.H. Infection and death from influenza A H1N1 virus in Mexico: A retrospective analysis. Lancet 2009, 374, 2072-2079. [CrossRef]

6. López-Cervantes, M.; Venado, A.; Moreno, A.; Pacheco-Domínguez, R.L.; Ortega-Pierres, G. On the spread of the novel influenza A (H1N1) virus in Mexico. J. Infect. Dev. Ctries. 2009, 3, 327-330. [CrossRef]

7. Wong, J.Y.; Kelly, H.; Cheung, C.-M.M.; Shiu, E.Y.; Wu, P.; Ni, M.Y.; Ip, D.K.M.; Cowling, B.J. Hospitalization Fatality Risk of Influenza A(H1N1)pdm09: A Systematic Review and Meta-Analysis. Am. J. Epidemiol. 2015, 182, 294-301. [CrossRef] [PubMed]

8. Kovalchik, S. The Comprehensive R Archive Network (CRAN). Download Content from NCBI Databases [R Package RISmed version 2.1.7]. Available online: https:/ / cran.r-project.org/web/packages/RISmed/index.html (accessed on 7 February 2021).

9. Package, T.; Clouds, T.W.; Fellows, A.I.; Rcpp, L. Package 'Wordcloud'. 2018. Available online: https://blogs.ntu.edu.sg/ ntulibrary/2019/08/16/free-word-cloud-generators / (accessed on 7 February 2021).

10. RStudio Team. RStudio: Integrated Development for R. 2015. Available online: https:/ /www.scirp.org/(S(oyulxb452alnt1aej1 nfow45)) / reference/ReferencesPapers.aspx?ReferenceID=2062239 (accessed on 7 February 2021). 
11. Meduri, G.U.; Kohler, G.; Headley, S.; Tolley, E.; Stentz, F.; Postlethwaite, A. Inflammatory cytokines in the BAL of patients with ARDS: Persistent elevation over time predicts poor outcome. Chest 1995, 108, 1303-1314. [CrossRef]

12. Danis, V.A.; Millington, M.; Hyland, V.J.; Grennan, D. Cytokine production by normal human monocytes: Inter-subject variation and relationship to an IL-1 receptor antagonist (IL-1Ra) gene polymorphism. Clin. Exp. Immunol. 2008, 99, 303-310. [CrossRef] [PubMed]

13. Knight, J.C.; Kwiatkowski, D. Inherited variability of tumor necrosis factor production and susceptibility to infectious disease. Proc. Assoc. Am. Phys. 1999, 111, 290-298. [CrossRef] [PubMed]

14. Antonopoulou, A.; Baziaka, F.; Tsaganos, T.; Raftogiannis, M.; Koutoukas, P.; Spyridaki, A.; Mouktaroudi, M.; Kotsaki, A.; Savva, A.; Georgitsi, M.; et al. Role of tumor necrosis factor gene single nucleotide polymorphisms in the natural course of 2009 influenza A H1N1 virus infection. Int. J. Infect. Dis. 2012, 16, e204-e208. [CrossRef] [PubMed]

15. Romanova, E.N.; Govorin, A.V. TNF- $\alpha$, IL-10, and eNOS gene polymorphisms in patients with influenza A/H1N1 complicated by pneumonia. Ter. Arkh. 2013, 85, 58-62. [PubMed]

16. Teijaro, J.R.; Walsh, K.B.; Cahalan, S.; Fremgen, D.M.; Roberts, E.; Scott, F.; Martinborough, E.; Peach, R.; Oldstone, M.B.A.; Rosen, H. Endothelial cells are central orchestrators of cytokine amplification during influenza virus infection. Cell 2011, 146, 980-991. [CrossRef] [PubMed]

17. Hagau, N.; Slavcovici, A.; Gonganau, D.N.; Oltean, S.; Dirzu, D.S.; Brezoszki, E.S.; Maxim, M.; Ciuce, C.; Mlesnite, M.; Gavrus, R.L.; et al. Clinical aspects and cytokine response in severe H1N1 influenza A virus infection. Crit. Care 2010, 14, R203. [CrossRef]

18. Reséndiz-Hernández, J.M.; Falfán-Valencia, R. Genetic polymorphisms and their involvement in the regulation of the inflammatory response in asthma and COPD. Adv. Clin. Exp. Med. 2018, 27, 125-133. [CrossRef]

19. Li, J.; Wang, Y.; Chang, X.; Han, Z. The effect of LTA gene polymorphisms on cancer risk: An updated systematic review and meta-analysis. Biosci. Rep. 2020, 40. [CrossRef]

20. Sinha, S.; Mishra, S.K.; Sharma, S.; Patibandla, P.K.; Mallick, P.K.; Sharma, S.K.; Mohanty, S.; Pati, S.S.; Mishra, S.K.; Ramteke, B.K.; et al. Polymorphisms of TNF-enhancer and gene for Fc $\gamma$ RIIa correlate with the severity of falciparum malaria in the ethnically diverse Indian population. Malar. J. 2008, 7, 13. [CrossRef]

21. Borja-Aburto, V.H.; Chowell, G.; Viboud, C.; Simonsen, L.; Miller, M.A.; Grajales-Muñiz, C.; González-Bonilla, C.R.; DiazQuiñones, J.A.; Echevarría-Zuno, S. Epidemiological Characterization of a Fourth Wave of Pandemic A/H1N1 Influenza in Mexico, Winter 2011-2012: Age Shift and Severity. Arch. Med. Res. 2012, 43, 563-570. [CrossRef] [PubMed]

22. Estella, A. Cytokine levels in bronchoalveolar lavage and serum in 3 patients with 2009 Influenza A(H1N1)v severe pneumonia. J. Infect. Dev. Ctries 2011, 5, 540-543. [CrossRef]

23. Martinez-Ocaña, J.; Olivo-Diaz, A.; Salazar-Dominguez, T.; Reyes-Gordillo, J.; Tapia-Aquino, C.; Martínez-Hernández, F.; Manjarrez, M.E.; Antonio-Martinez, M.; Contreras-Molina, A.; Figueroa-Moreno, R.; et al. Plasma cytokine levels and cytokine gene polymorphisms in Mexican patients during the influenza pandemic A(H1N1)pdm09. J. Clin. Virol. 2013, 58, 108-113. [CrossRef] [PubMed]

24. Pebody, R.; Hardelid, P.; Fleming, D.M.; McMenamin, J.; Andrews, N.; Robertson, C.; Thomas, D.R.; SebastianPillai, P.; Ellis, J.; Carman, W.; et al. Effectiveness of seasonal 2010/11 and pandemic influenza A(H1N1)2009 vaccines in preventing influenza infection in the United Kingdom: Mid-season analysis 2010/11. Eurosurveillance 2011, 16, 19791.

25. Hardelid, P.; Fleming, D.M.; Mcmenamin, J.; Andrews, N.; Robertson, C.; SebastianPillai, P.; Ellis, J.; Carman, W.; Wreghitt, T.; Watson, J.M.; et al. Effectiveness of pandemic and seasonal influenza vaccine in preventing pandemic influenza A(H1N1)2009 infection in England and Scotland 2009-2010. Eurosurveillance 2011, 16, 19763. [PubMed]

26. Zúñiga, J.; Torres, M.; Romo, J.; Torres, D.; Jiménez, L.; Ramírez, G.; Cruz, A.; Espinosa, E.; Herrera, T.; Buendía, I.; et al. Inflammatory profiles in severe pneumonia associated with the pandemic influenza A/H1N1 virus isolated in Mexico City. Autoimmunity 2011, 44, 562-570. [CrossRef] [PubMed]

27. Koyama, S.; Aoshi, T.; Tanimoto, T.; Kumagai, Y.; Kobiyama, K.; Tougan, T.; Sakurai, K.; Coban, C.; Horii, T.; Akira, S.; et al. Plasmacytoid dendritic cells delineate immunogenicity of influenza vaccine subtypes. Sci. Transl. Med. 2010, 2, 25ra24. [CrossRef]

28. Yu, G.-I.; Ha, E.; Park, S.-H.; Park, J.-H.; Jang, H.-S.; Bae, J.-H.; Chung, I.-S.; Shin, N.-H.; Song, D.-K. Association of tumor necrosis factor- $\alpha$ (TNF- $\alpha$ ) promoter polymorphisms with overweight/obesity in a Korean population. Inflamm. Res. 2011, 60, 1099-1105. [CrossRef]

29. Goraya, M.U.; Zaighum, F.; Sajjad, N.; Anjum, F.R.; Sakhawat, I.; Rahman, S.U. Web of interferon stimulated antiviral factors to control the influenza A viruses replication. Microb. Pathog. 2020, 139. [CrossRef] [PubMed]

30. Tsai, S.-Y.; Segovia, J.A.; Chang, T.-H.; Morris, I.R.; Berton, M.T.; Tessier, P.A.; Tardif, M.R.; Cesaro, A.; Bose, S. DAMP Molecule S100A9 Acts as a Molecular Pattern to Enhance Inflammation during Influenza A Virus Infection: Role of DDX21-TRIF-TLR4MyD88 Pathway. PLoS Pathog. 2014, 10, e1003848. [CrossRef]

31. Akira, S.; Uematsu, S.; Takeuchi, O. Pathogen recognition and innate immunity. Cell 2006, 124, 783-801. [CrossRef]

32. Kawai, T.; Akira, S. Innate immune recognition of viral infection. Nat. Immunol. 2006, 7, 131-137. [CrossRef] [PubMed]

33. Honda, K.; Takaoka, A.; Taniguchi, T. Type I Inteferon Gene Induction by the Interferon Regulatory Factor Family of Transcription Factors. Immunity 2006, 25, 349-360. [CrossRef] [PubMed]

34. Du, S.; Jiang, Y.; Xu, W.; Bai, J.; Tian, M.; Wang, M.; Wang, Y.; Cao, T.; Song, L.; Jiang, Y.; et al. Construction, expression and antiviral activity analysis of recombinant adenovirus expressing human IFITM3 in vitro. Int. J. Biol. Macromol. 2019, 131, 925-932. [CrossRef] 
35. Iwasaki, A.; Medzhitov, R. A New Shield for a Cytokine Storm. Cell 2011, 146, 861-862. [CrossRef]

36. Clark, I.A. The advent of the cytokine storm. Immunol. Cell Biol. 2007, 85, 271-273. [CrossRef]

37. Wang, Q.; Fang, P.; He, R.; Li, M.; Yu, H.; Zhou, L.; Yi, Y.; Wang, F.; Rong, Y.; Zhang, Y.; et al. O-GlcNAc transferase promotes influenza A virus-induced cytokine storm by targeting interferon regulatory factor-5. Sci. Adv. 2020, 6, 16. [CrossRef]

38. Lee, N.; Wong, C.K.; Hui, D.S.C.; Lee, S.K.W.; Wong, R.Y.K.; Ngai, K.L.K.; Chan, M.C.W.; Chu, Y.J.; Ho, A.W.Y.; Lui, G.C.Y.; et al. Role of human Toll-like receptors in naturally occurring influenza A infections. Influ. Other Respir. Viruses 2013, 7, 666-675. [CrossRef] [PubMed]

39. Zhang, W.; He, T.; Wang, Q.; Li, X.; Wei, J.; Hou, X.; Zhang, B.; Huang, L.; Wang, L. Interleukin-1 receptor-associated kinase-2 genetic variant rs708035 increases NF-kB activity through promoting TRAF6 ubiquitination. J. Biol. Chem. 2014, 289, 12507-12519. [CrossRef] [PubMed]

40. Verhelst, J.; Van Hoecke, L.; Spitaels, J.; De Vlieger, D.; Kolpe, A.; Saelens, X. Chemical-controlled Activation of Antiviral Myxovirus Resistance Protein 1. J. Biol. Chem. 2017, 292, 2226-2236. [CrossRef] [PubMed]

41. Verhelst, J.; Hulpiau, P.; Saelens, X. Mx Proteins: Antiviral Gatekeepers That Restrain the Uninvited. Microbiol. Mol. Biol. Rev. 2013, 77, 551-566. [CrossRef]

42. Siegrist, F.; Ebeling, M.; Certa, U. The Small Interferon-Induced Transmembrane Genes and Proteins. J. Interf. Cytokine Res. 2011, 31, 183-197. [CrossRef]

43. Zhao, X.; Li, J.; Winkler, C.A.; An, P.; Guo, J.-T. IFITM Genes, Variants, and Their Roles in the Control and Pathogenesis of Viral Infections. Front. Microbiol. 2019, 9, 3228. [CrossRef] [PubMed]

44. Kim, Y.-C.; Jeong, M.-J.; Jeong, B.-H. Genetic characteristics and polymorphisms in the chicken interferon-induced transmembrane protein (IFITM3) gene. Vet. Res. Commun. 2019, 43, 203-214. [CrossRef] [PubMed]

45. Zhao, X.; Guo, F.; Liu, F.; Cuconati, A.; Chang, J.; Block, T.M.; Guo, J.-T. Interferon induction of IFITM proteins promotes infection by human coronavirus OC43. Proc. Natl. Acad. Sci. USA 2014, 111, 6756-6761. [CrossRef] [PubMed]

46. Allen, E.K.; Randolph, A.G.; Bhangale, T.; Dogra, P.; Ohlson, M.; Oshansky, C.M.; Zamora, A.E.; Shannon, J.P.; Finkelstein, D.; Dressen, A.; et al. SNP-mediated disruption of CTCF binding at the IFITM3 promoter is associated with risk of severe influenza in humans. Nat. Med. 2017, 23, 975-983. [CrossRef]

47. Brass, A.L.; Huang, I.-C.; Benita, Y.; John, S.P.; Krishnan, M.N.; Feeley, E.M.; Ryan, B.J.; Weyer, J.L.; Van Der Weyden, L.; Fikrig, E.; et al. The IFITM Proteins Mediate Cellular Resistance to Influenza A H1N1 Virus, West Nile Virus, and Dengue Virus. Cell 2009, 139, 1243-1254. [CrossRef]

48. Zani, A.; Zhang, L.; McMichael, T.M.; Kenney, A.D.; Chemudupati, M.; Kwiek, J.J.; Liu, S.L.; Yount, J.S. Interferon-induced transmembrane proteins inhibit cell fusion mediated by trophoblast syncytins. J. Biol. Chem. 2019, 294, 19844-19851. [CrossRef] [PubMed]

49. Feeley, E.M.; Sims, J.S.; John, S.P.; Chin, C.R.; Pertel, T.; Chen, L.-M.; Gaiha, G.D.; Ryan, B.J.; Donis, R.O.; Elledge, S.J.; et al. IFITM3 Inhibits Influenza A Virus Infection by Preventing Cytosolic Entry. PLoS Pathog. 2011, 7, e1002337. [CrossRef] [PubMed]

50. Jia, R.; Pan, Q.; Ding, S.; Rong, L.; Liu, S.-L.; Geng, Y.; Qiao, W.; Liang, C. The N-Terminal Region of IFITM3 Modulates Its Antiviral Activity by Regulating IFITM3 Cellular Localization. J. Virol. 2012, 86, 13697-13707. [CrossRef] [PubMed]

51. Kenney, A.D.; McMichael, T.M.; Imas, A.; Chesarino, N.M.; Zhang, L.; Dorn, L.E.; Wu, Q.; Alfaour, O.; Amari, F.; Chen, M.; et al. IFITM3 protects the heart during influenza virus infection. Proc. Natl. Acad. Sci. USA 2019, 116, 18607-18612. [CrossRef]

52. Kenney, A.; Imas, A.; Rajaram, M.; Yount, J. IFITM3 is cardioprotective during influenza virus infection. J. Immunol. 2018, 200, 60.

53. WHO. WHO Public Health Research Agenda for Influenza; WHO: Geneva, Switzerland, 2010.

54. König, R.; Stertz, S.; Zhou, Y.; Inoue, A.; Hoffmann, H.-H.; Bhattacharyya, S.; Alamares, J.G.; Tscherne, D.M.; Ortigoza, M.B.; Liang, Y.; et al. Human host factors required for influenza virus replication. Nature 2010, 463, 813-817. [CrossRef]

55. Single Nucleotide Polymorphisms (SNPs). In Talking Glossary of Genetic Terms. Available online: https://www.genome.gov/ genetics-glossary / Single-Nucleotide-Polymorphisms (accessed on 7 February 2021).

56. Iuliano, A.D.; Roguski, K.M.; Chang, H.H.; Muscatello, D.J.; Palekar, R.; Tempia, S.; Cohen, C.; Gran, J.M.; Schanzer, D.; Cowling, B.J.; et al. Estimates of global seasonal influenza-associated respiratory mortality: A modelling study. Lancet 2018, 391, 1285-1300. [CrossRef]

57. Zuñiga, J.; Buendia-Roldan, I.; Zhao, Y.; Jiménez, L.; Torres, D.; Romo, J.; Ramirez, G.; Cruz, A.; Vargas-Alarcon, G.; Sheu, C.-C.; et al. Genetic variants associated with severe pneumonia in A/H1N1 influenza infection. Eur. Respir. J. 2012, 39, 604-610. [CrossRef] [PubMed]

58. Monsalvo, A.C.; Batalle, J.P.; Lopez, M.F.; Krause, J.C.; Klemenc, J.; Hernandez, J.Z.; Maskin, B.; Bugna, J.; Rubinstein, C.; Aguilar, L.; et al. Severe pandemic 2009 H1N1 influenza disease due to pathogenic immune complexes. Nat. Med. 2010, 17, 195-199. [CrossRef]

59. Nagelkerke, S.Q.; Schmidt, D.E.; De Haas, M.; Kuijpers, T.W. Genetic Variation in Low-To-Medium-Affinity Fc $\gamma$ Receptors: Functional Consequences, Disease Associations, and Opportunities for Personalized Medicine. Front. Immunol. 2019, 10, 2237. [CrossRef] [PubMed]

60. Khor, C.C.; Davila, S.; Breunis, W.B.; Lee, Y.-C.; Shimizu, C.; Wright, V.J.; Yeung, R.S.M.; Tan, D.E.K.; Sim, K.S.; Wang, J.J.; et al. Genome-wide association study identifies FCGR2A as a susceptibility locus for Kawasaki disease. Nat. Genet. 2011, 43, 1241-1246. [CrossRef] [PubMed] 
61. Clark, M.R.; Stuart, S.G.; Kimberly, R.P.; Ory, P.A.; Goldstein, I.M. A single amino acid distinguishes the high-responder from the low-responder form of Fc receptor II on human monocytes. Eur. J. Immunol. 1991, 21, 1911-1916. [CrossRef]

62. Chatzopoulou, F.; Gioula, G.; Kioumis, I.; Chatzidimitriou, D.; Exindari, M. Identification of complement-related host genetic risk factors associated with influenza A(H1N1)pdm09 outcome: Challenges ahead. Med. Microbiol. Immunol. 2019, 208, 631-640. [CrossRef]

63. Peterson, K.L.; Zhanga, W.; Lu, P.D.; Keilbaugh, S.A.; Peerschke, E.I.; Ghebrehiwetab, B. The C1q-Binding Cell Membrane Proteins cC1q-R and gC1q-R Are Released from Activated Cells: Subcellular Distribution and Immunochemical Characterization. Clin. Immunol. Immunopathol. 1997, 84, 17-26. [CrossRef]

64. Chen, J.-Z.; Huang, S.-D.; Ji, C.-N.; Pang, R.-Y.; Xie, Y.; Xue, J.-L. Identification, Expression Pattern, and Subcellular Location of Human RIP Isoforms. DNA Cell Biol. 2005, 24, 464-469. [CrossRef]

65. Lee, N.; Cao, B.; Ke, C.; Lu, H.; Hu, Y.; Tam, C.H.T.; Ma, R.C.W.; Guan, D.; Zhu, Z.; Li, H.; et al. IFITM3, TLR3, and CD55 Gene SNPs and Cumulative Genetic Risks for Severe Outcomes in Chinese Patients With H7N9/H1N1pdm09 Influenza. J. Infect. Dis. 2017, 216, 97-104. [CrossRef]

66. Zhou, J.; To, K.K.-W.; Dong, H.; Cheng, Z.-S.; Lau, C.C.-Y.; Poon, V.K.M.; Fan, Y.-H.; Song, Y.-Q.; Tse, H.; Chan, K.-H.; et al. A Functional Variation in CD55 Increases the Severity of 2009 Pandemic H1N1 Influenza A Virus Infection. J. Infect. Dis. 2012, 206, 495-503. [CrossRef] [PubMed]

67. Garcia-Etxebarria, K.; Bracho, M.A.; Galán, J.C.; Pumarola, T.; Castilla, J.; De Lejarazu, R.O.; Rodríguez-Domínguez, M.; Quintela, I.; Bonet, N.; García-Garcerà, M.; et al. No major host genetic risk factor contributed to A(H1N1)2009 influenza severity. PLoS ONE 2015, 10, e0141661. [CrossRef] [PubMed]

68. Yu, Z.; Sánchez-Velar, N.; Catrina, I.E.; Kittler, E.L.W.; Udofia, E.B.; Zapp, M.L. The cellular HIV-1 Rev cofactor hRIP is required for viral replication. Proc. Natl. Acad. Sci. USA 2005, 102, 4027-4032. [CrossRef]

69. O'Neill, R.E.; Talon, J.; Palese, P. The influenza virus NEP (NS2 protein) mediates the nuclear export of viral ribonucleoproteins. EMBO J. 1998, 17, 288-296. [CrossRef] [PubMed]

70. Wellington, D.; Laurenson-Schafer, H.; Abdel-Haq, A.; Dong, T. IFITM3: How genetics influence influenza infection demographically. Biomed. J. 2019, 42, 19-26. [CrossRef]

71. David, S.; Correia, V.; Antunes, L.; Faria, R.; Ferrão, J.; Faustino, P.; Nunes, B.; Maltez, F.; Lavinha, J.; De Andrade, H.R. Population genetics of IFITM3 in Portugal and Central Africa reveals a potential modifier of influenza severity. Immunogenetics 2018, 70, 169-177. [CrossRef]

72. $\quad$ Everitt, A.R.; Clare, S.; Pertel, T.; John, S.P.; Wash, R.S.; Smith, S.E.; Chin, C.R.; Feeley, E.M.; Sims, J.S.; Adams, D.J.; et al. IFITM3 restricts the morbidity and mortality associated with influenza. Nature 2012, 484, 519-523. [CrossRef]

73. Compton, A.A.; Roy, N.; Porrot, F.; Billet, A.; Casartelli, N.; Yount, J.S.; Liang, C.; Schwartz, O. Natural mutations in IFITM 3 modulate post-translational regulation and toggle antiviral specificity. EMBO Rep. 2016, 17, 1657-1671. [CrossRef]

74. Yang, X.; Tan, B.; Zhou, X.; Xue, J.; Zhang, X.; Wang, P.; Shao, C.; Li, Y.; Li, C.; Xia, H.; et al. Interferon-Inducible Transmembrane Protein 3 Genetic Variant rs12252 and Influenza Susceptibility and Severity: A Meta-Analysis. PLoS ONE 2015, 10, e0124985. [CrossRef] [PubMed]

75. López-Rodríguez, M.; Herrera-Ramos, E.; Solé-Violán, J.; Ruíz-Hernández, J.J.; Borderías, L.; Horcajada, J.P.; Lerma-Chippirraz, E.; Rajas, O.; Briones, M.; Pérez-González, M.C.; et al. IFITM3 and severe influenza virus infection. No evidence of genetic association. Eur. J. Clin. Microbiol. Infect. Dis. 2016, 35, 1811-1817. [CrossRef]

76. Ensembl Genome Browser 99. Available online: https://www.ensembl.org/index.html (accessed on 5 April 2020).

77. López-Jiménez, J.J.; Peña-Iñiguez, D.I.; Fletes-Rayas, A.L.; Flores-Martínez, S.E.; Sánchez-Corona, J.; Rosales-Gomez, R.C.; Montoya-Fuentes, H. Distribution of IFITM3 polymorphism (dbSNP: rs12252) in mestizo populations in four states of Mexico. Int. J. Immunogenetics 2018, 45, 146-151. [CrossRef] [PubMed]

78. Wilson, A.G.; Symons, J.A.; McDowell, T.L.; McDevitt, H.O.; Duff, G.W. Effects of a polymorphism in the human tumor necrosis factor promoter on transcriptional activation. Proc. Natl. Acad. Sci. USA 1997, 94, 3195-3199. [CrossRef]

79. Almansa, R.; Anton, A.; Ramirez, P.; Martin-Loeches, I.; Banner, D.; Pumarola, T.; Xu, L.; Blanco, J.; Ran, L.; Lopez-Campos, G.; et al. Direct association between pharyngeal viral secretion and host cytokine response in severe pandemic influenza. BMC Infect. Dis. 2011, 11, 232. [CrossRef]

80. Bermejo-Martin, J.F.; Ortiz de Lejarazu, R.; Pumarola, T.; Rello, J.; Almansa, R.; Ramírez, P.; Martin-Loeches, I.; Varillas, D.; Gallegos, M.C.; Serón, C.; et al. Th1 and Th17 hypercytokinemia as early host response signature in severe pandemic influenza. Crit. Care. 2009, 13, R201. [CrossRef] [PubMed]

81. Betakova, T.; Kostrabova, A.; Lachova, V.; Turianova, L. Cytokines Induced During Influenza Virus Infection. Curr. Pharm. Des. 2017, 23, 18. [CrossRef]

82. To, K.K.W.; Hung, I.F.N.; Li, I.W.S.; Lee, K.; Koo, C.; Yan, W.; Liu, R.; Ho, K.Y.; Chu, K.H.; Watt, C.L.; et al. Delayed Clearance of Viral Load and Marked Cytokine Activation in Severe Cases of Pandemic H1N1 2009 Influenza Virus Infection. Clin. Infect. Dis. 2010, 50, 850-859. [CrossRef] [PubMed]

83. De Jong, M.D.; Simmons, C.P.; Thanh, T.T.; Hien, V.M.; Smith, G.J.D.; Chau, T.N.B.; Hoang, D.M.; Chau, N.V.V.; Khanh, T.H.; Dong, V.C.; et al. Fatal outcome of human influenza A (H5N1) is associated with high viral load and hypercytokinemia. Nat. Med. 2006, 12, 1203-1207. [CrossRef] 
84. Zeng, H.; Belser, J.A.; Goldsmith, C.S.; Gustin, K.M.; Veguilla, V.; Katz, J.M.; Tumpey, T.M. A(H7N9) Virus Results in Early Induction of Proinflammatory Cytokine Responses in both Human Lung Epithelial and Endothelial Cells and Shows Increased Human Adaptation Compared with Avian H5N1 Virus. J. Virol. 2015, 89, 4655-4667. [CrossRef] [PubMed]

85. Shen, Z.; Chen, Z.; Li, X.; Xu, L.; Guan, W.; Cao, Y.; Hu, Y.; Zhang, J. Host immunological response and factors associated with clinical outcome in patients with the novel influenza A H7N9 infection. Clin. Microbiol. Infect. 2014, 20, O493-O500. [CrossRef]

86. Falfán-Valencia, R. Factor de necrosis tumoral: Actividad biológica en neumopatías intersticiales. Rev. Inst. Nal. Enf. Resp. Mex. 2002, 15, 48-53.

87. Buendía-Roldán, I.; Santiago-Ruiz, L.; Pérez-Rubio, G.; Mejía, M.; Rojas-Serrano, J.; Ambrocio-Ortiz, E.; Benítez-Valdez, G.; Selman, M.; Falfán-Valencia, R. A major genetic determinant of autoimmune diseases is associated with the presence of autoantibodies in hypersensitivity pneumonitis. Eur. Respir. J. 2020, 56, 1901380. [CrossRef]

88. Ambrocio-Ortiz, E.; Galicia-Negrete, G.; Pérez-Rubio, G.; Escobar-Morales, A.J.; Abarca-Rojano, E.; Del Angel-Pablo, A.D.; Castillejos-López, M.D.J.; Falfán-Valencia, R. Single Nucleotide and Copy-Number Variants in IL4 and IL13 Are Not Associated with Asthma Susceptibility or Inflammatory Markers: A Case-Control Study in a Mexican-Mestizo Population. Diagnostics 2020, 10, 273. [CrossRef] [PubMed]

89. Ponce-Gallegos, M.A.; Pérez-Rubio, G.; Ambrocio-Ortiz, E.; Partida-Zavala, N.; Hernández-Zenteno, R.; Flores-Trujillo, F.; García-Gómez, L.; Hernández-Pérez, A.; Ramírez-Venegas, A.; Falfán-Valencia, R. Genetic variants in IL17A and serum levels of IL-17A are associated with COPD related to tobacco smoking and biomass burning. Sci. Rep. 2020, 10, 1-11.

90. Pérez-Rubio, G.; Córdoba-Lanús, E.; Cupertino, P.; Cartujano-Barrera, F.; Campos, M.A.; Falfán-Valencia, R. Role of Genetic Susceptibility in Nicotine Addiction and Chronic Obstructive Pulmonary Disease. Rev. Investig. Clin. 2019, 71, 36-54. [CrossRef]

91. Pavón-Romero, G.F.; Pérez-Rubio, G.; Ramírez-Jiménez, F.; Ambrocio-Ortiz, E.; Merino-Camacho, C.R.; Falfán-Valencia, R.; Teran, L.M. IL10 rs1800872 Is Associated with Non-Steroidal Anti-Inflammatory Drugs Exacerbated Respiratory Disease in Mexican-Mestizo Patients. Biomolecules 2020, 10, 104. [CrossRef] [PubMed]

92. Ambrocio-Ortiz, E.; Pérez-Rubio, G.; Ramírez-Venegas, A.; Hernández-Zenteno, R.; Del Angel-Pablo, A.D.; Pérez-Rodríguez, M.E.; Salazar, A.M.; Abarca-Rojano, E.; Falfán-Valencia, R. Effect of SNPs in HSP Family Genes, Variation in the mRNA and Intracellular Hsp Levels in COPD Secondary to Tobacco Smoking and Biomass-Burning Smoke. Front. Genet. 2020, 10. [CrossRef]

93. Rood, M.J.; Van Krugten, M.V.; Zanelli, E.; Van Der Linden, M.W.; Keijsers, V.; Schreuder, G.M.T.; Verduyn, W.; Westendorp, R.G.J.; De Vries, R.R.P.; Breedveld, F.C.; et al. TNF-308A and HLA-DR3 alleles contribute independently to susceptibility to systemic lupus erythematosus. Arthritis Rheum. 2000, 43, 129-134. [CrossRef]

94. Zúñiga, J.; Vargas-Alarcon, G.; Hernández-Pacheco, G.; Portal-Celhay, C.; Yamamoto-Furusho, J.K.; Granados, J. Tumor necrosis factor- $\alpha$ promoter polymorphisms in Mexican patients with systemic lupus erythematosus (SLE). Genes Immunol. 2001, 2, 363-366. [CrossRef]

95. Jiménez-Morales, S.; Velázquez-Cruz, R.; Ramírez-Bello, J.; Bonilla-González, E.; Romero-Hidalgo, S.; Escamilla-Guerrero, G.; Cuevas, F.; Espinosa-Rosales, F.; Martínez-Aguilar, N.E.; Gómez-Vera, J.; et al. Tumor necrosis factor-alpha is a common genetic risk factor for asthma, juvenile rheumatoid arthritis, and systemic lupus erythematosu1. Hum. Immunol. 2009, 70, 251-256. [CrossRef]

96. Parks, C.G.; Pandey, J.P.; Dooley, M.A.; Treadwell, E.L.; Clair, E.S.; Gilkeson, G.S.; A Feghali-Bostwick, C.; Cooper, G.S. Genetic polymorphisms in tumor necrosis factor (TNF)- $\alpha$ and TNF- $\beta$ in a population-based study of systemic lupus erythematosus: Associations and interaction with the interleukin- $1 \alpha-889 \mathrm{C} / \mathrm{T}$ polymorphism. Hum. Immunol. 2004, 65, 622-631. [CrossRef] [PubMed]

97. Fernández-Mestre, M.; Gendzekhadze, K.; Rivas-Vetencourt, P.; Layrisse, Z. TNF-alpha-308A allele, a possible severity risk factor of hemorrhagic manifestation in dengue fever patients. Tissue Antigens 2004, 64, 469-472. [CrossRef] [PubMed]

98. Alagarasu, K.; Mulay, A.; Singh, R.; Gavade, V.; Shah, P.; Cecilia, D. Association of HLA-DRB1 and TNF genotypes with dengue hemorrhagic fever. Hum. Immunol. 2013, 74, 610-617. [CrossRef]

99. García-Trejo, A.R.; Falcón-Lezama, J.A.; Juárez-Palma, L.; Granados, J.; Zúñiga-Ramos, J.; Rangel, H.; Barquera, R.; VargasAlarcón, G.; Ramos, C. Tumor necrosis factor alpha promoter polymorphisms in Mexican patients with dengue fever. Acta Trop. 2011, 120, 67-71. [CrossRef]

100. Liu, C.J.; Wong, Y.K.; Chang, K.W.; Chang, H.C.; Liu, H.F.; Lee, Y.J. Tumor necrosis factor- $\alpha$ promoter polymorphism is associated with susceptibility to oral squamous cell carcinoma. J. Oral. Pathol. Med. 2005, 34, 608-612. [CrossRef]

101. Azmy, I.A.F.; Balasubramanian, S.P.; Wilson, A.G.; Stephenson, T.J.; Cox, A.; Brown, N.J.; Reed, M.W.R. Role of tumour necrosis factor gene polymorphisms (-308 and -238) in breast cancer susceptibility and severity. Breast Cancer Res. 2004, 6, R395-R400. [CrossRef] [PubMed]

102. Shih, C.M.; Lee, Y.L.; Chiou, H.L.; Chen, W.; Chang, G.C.; Chou, M.C.; Lin, L.Y. Association of TNF- $\alpha$ polymorphism with susceptibility to and severity of non-small cell lung cancer. Lung Cancer 2006, 52, 15-20. [CrossRef]

103. Morales-García, G.; Falfán-Valencia, R.; García-Ramírez, R.A.; Camarena, Á.; Ramirez-Venegas, A.; Castillejos-López, M.; PérezRodríguez, M.; González-Bonilla, C.; Grajales-Muñíz, C.; Borja-Aburto, V.; et al. Pandemic influenza A/H1N1 virus infection and TNF, LTA, IL1B, IL6, IL8, and CCL polymorphisms in Mexican population: A case-control study. BMC Infect. Dis. 2012, 12, 299. [CrossRef] [PubMed] 
104. Garcia-Ramirez, R.A.; Ramirez-Venegas, A.; Quintana-Carrillo, R.; Camarena, Á.E.; Falfán-Valencia, R.; Mejía-Aranguré, J.M. TNF, IL6, and IL1B Polymorphisms Are Associated with Severe Influenza A (H1N1) Virus Infection in the Mexican Population. PLoS ONE 2015, 10, e0144832. [CrossRef]

105. Elsayed, S.M.; Hassanein, O.M.; Hassan, N.H.A. Influenza A (H1N1) virus infection and TNF-308, IL6, and IL8 polymorphisms in Egyptian population: A case-control study. J. Basic Appl. Zool. 2019, 80, 1. [CrossRef]

106. Sultana, Z.; Bankura, B.; Pattanayak, A.K.; Sengupta, D.; Sengupta, M.; Saha, M.L.; Panda, C.K.; Das, M. Association of Interleukin1 beta and tumor necrosis factor-alpha genetic polymorphisms with gastric cancer in India. Environ. Mol. Mutagen. 2018, 59, 653-667. [CrossRef]

107. Martínez-Carrillo, D.N.; Garza-González, E.; Betancourt-Linares, R.; Mónico-Manzano, T.; Antúnez-Rivera, C.; Román-Román, A.; Flores-Alfaro, E.; Illades-Aguiar, B.; Fernández-Tilapa, G. Association of IL1B -511C/-31T haplotype and Helicobacter pylori vacA genotypes with gastric ulcer and chronic gastritis. BMC Gastroenterol. 2010, 10, 126-128. [CrossRef]

108. Sun, X.; Cai, H.; Li, Z.; Li, S.; Yin, W.; Dong, G.; Kuai, J.; He, Y.; Jia, J. Association Between IL-1 $\beta$ Polymorphisms and Gastritis Risk: A Meta-Analysis. Medicine 2017, 96, e6001. [CrossRef] [PubMed]

109. Keshavarz, M.; Namdari, H.; Farahmand, M.; Mehrbod, P.; Mokhtari-Azad, T.; Rezaei, F. Association of polymorphisms in inflammatory cytokines encoding genes with severe cases of influenza A/H1N1 and B in an Iranian population. Virol. J. 2019, 16, 79. [CrossRef]

110. Liu, Y.; Li, S.; Zhang, G.; Nie, G.; Meng, Z.; Mao, D.; Chen, C.; Chen, X.; Zhou, B.; Zeng, G. Genetic variants in IL1A and IL1B contribute to the susceptibility to 2009 pandemic H1N1 influenza A virus. BMC Immunol. 2013, 14, 37. [CrossRef] [PubMed]

111. IL1B Interleukin 1 Beta [Homo Sapiens (Human)]; Gene 3553; NCBI: Bethesda, MD, USA, 2021.

112. IL1A Interleukin 1 Alpha [Homo Sapiens (Human)]; Gene 3552; NCBI: Bethesda, MD, USA, 2021.

113. Dinarello, C.A. IL-1: Discoveries, controversies and future directions. Eur. J. Immunol. 2010, 40, 599-606. [CrossRef] [PubMed]

114. Murphy, E.A.; Davis, J.M.; McClellan, J.L.; Carmichael, M.D.; Van Rooijen, N.; Gangemi, J.D. Susceptibility to Infection and Inflammatory Response Following Influenza Virus (H1N1, A/PR/8/34) Challenge: Role of Macrophages. J. Interf. Cytokine Res. 2011, 31, 501-508. [CrossRef] [PubMed]

115. rs17561 RefSNP; Report dbSNP; NCBI: Bethesda, MD, USA, 2020.

116. Nguyen-Van-Tam, J.S. 2009 pandemic influenza A/H1N1. In Environmental Medicine; CRC Press: Boca Raton, FL, USA, 2010; pp. 221-223.

117. Allen, I.C.; Scull, M.A.; Moore, C.B.; Holl, E.K.; McElvania-TeKippe, E.; Taxman, D.J.; Guthrie, E.H.; Pickles, R.J.; Ting, J.P.-Y. The NLRP3 Inflammasome Mediates In Vivo Innate Immunity to Influenza A Virus through Recognition of Viral RNA. Immunity 2009, 30, 556-565. [CrossRef]

118. Ichinohe, T.; Pang, I.K.-S.; Iwasaki, A. Influenza virus activates inflammasomes via its intracellular M2 ion channel. Nat. Immunol. 2010, 11, 404-410. [CrossRef]

119. Hornung, V.; Ablasser, A.; Charrel-Dennis, M.; Bauernfeind, F.G.; Horvath, G.; Caffrey, D.R.; Latz, E.; Fitzgerald, K.A. AIM2 recognizes cytosolic dsDNA and forms a caspase-1-activating inflammasome with ASC. Nat. Cell Biol. 2009, 458, 514-518. [CrossRef]

120. Luft, T.; Jefford, M.; Luetjens, P.; Hochrein, H.; Masterman, K.-A.; Maliszewski, C.; Shortman, K.; Cebon, J.; Maraskovsky, E. IL-1 $\beta$ Enhances CD40 Ligand-Mediated Cytokine Secretion by Human Dendritic Cells (DC): A Mechanism for T Cell-Independent DC Activation. J. Immunol. 2002, 168, 713-722. [CrossRef]

121. Acosta-Rodriguez, E.V.; Napolitani, G.; Lanzavecchia, A.; Sallusto, F. Interleukins $1 \beta$ and 6 but not transforming growth factor- $\beta$ are essential for the differentiation of interleukin 17-producing human T helper cells. Nat. Immunol. 2007, 8, 942-949. [CrossRef] [PubMed]

122. Rogo, L.D.; Rezaei, F.; Marashi, S.M.; Yekaninejad, M.S.; Naseri, M.; Ghavami, N.; Mokhtari-Azad, T. Seasonal influenza A/H3N2 virus infection and IL-1B, IL-10, IL-17, and IL-28 polymorphisms in Iranian population. J. Med. Virol. 2016, 88, 2078-2084. [CrossRef]

123. Narasaraju, T.; Yang, E.; Samy, R.P.; Ng, H.H.; Poh, W.P.; Liew, A.-A.; Phoon, M.C.; van Rooijen, N.; Chow, V.T. Excessive Neutrophils and Neutrophil Extracellular Traps Contribute to Acute Lung Injury of Influenza Pneumonitis. Am. J. Pathol. 2011, 179, 199-210. [CrossRef]

124. Akaike, T.; Noguchi, Y.; Ijiri, S.; Setoguchi, K.; Suga, M.; Zheng, Y.M.; Dietzschold, B.; Maeda, H. Pathogenesis of influenza virus-induced pneumonia: Involvement of both nitric oxide and oxygen radicals. Proc. Natl. Acad. Sci. USA 1996, 93, $2448-2453$. [CrossRef] [PubMed]

125. Schwindinger, W.F.; Robishaw, J.D. Heterotrimeric G-protein $\beta \gamma$-dimers in growth and differentiation. Oncogene 2001, 20, 1653-1660. [CrossRef] [PubMed]

126. Garcia, C.C.; Tavares, L.P.; Dias, A.C.F.; Kehdy, F.; Alvarado-Arnez, L.E.; Queiroz-Junior, C.M.; Galvão, I.; Lima, B.H.; Matos, A.R.; Gonçalves, A.P.F.; et al. Phosphatidyl Inositol 3 Kinase-Gamma Balances Antiviral and Inflammatory Responses during Influenza A H1N1 Infection: From Murine Model to Genetic Association in Patients. Front. Immunol. 2018, 9. [CrossRef]

127. Shiina, T.; Hosomichi, K.; Inoko, H.; Kulski, J.K. The HLA genomic loci map: Expression, interaction, diversity and disease. J. Hum. Genet. 2009, 54, 15-39. [CrossRef]

128. Matzaraki, V.; Kumar, V.; Wijmenga, C.; Zhernakova, A. The MHC locus and genetic susceptibility to autoimmune and infectious diseases. Genome Biol. 2017, 18, 1-21. [CrossRef] [PubMed] 
129. Zhao, Y.; Zhang, Y.H.; Denney, L.; Young, D.; Powell, T.J.; Peng, Y.C.; Li, N.; Yan, H.P.; Wang, D.Y.; Shu, Y.L.; et al. High levels of virus-specific CD4+ T cells predict severe pandemic influenza A virus infection. Am. J. Respir. Crit. Care Med. 2012, 186, $1292-1297$. [CrossRef]

130. Wagar, L.E.; Rosella, L.; Crowcroft, N.; Lowcock, B.; Drohomyrecky, P.C.; Foisy, J.; Gubbay, J.; Rebbapragada, A.; Winter, A.L.; Achonu, C.; et al. Humoral and cell-mediated immunity to pandemic H1N1 influenza in a Canadian cohort one year post-pandemic: Implications for vaccination. PLoS ONE 2011, 6, e28063. [CrossRef]

131. Fox, A.; Hoa, L.N.M.; Horby, P.; van Doorn, H.R.; Trung, N.V.; Ha, N.H.; Nguyen, T.C.; Vu, D.P.; Nguyen, M.H.; Diep, N.T.N.; et al. Severe pandemic H1N1 2009 infection is associated with transient NK and T deficiency and aberrant CD8 responses. PLoS ONE 2012, 7, e31535. [CrossRef] [PubMed]

132. Doherty, P.C.; Turner, S.J.; Webby, R.G.; Thomas, P.G. Influenza and the challenge for immunology. Nat. Immunol. 2006, 7, 449-455. [CrossRef] [PubMed]

133. Wang, C.; Zhang, Y.; Wu, B.; Liu, S.; Xu, P.; Lu, Y.; Luo, J.; Nolte, D.L.; Deliberto, T.J.; Duan, M.; et al. Evolutionary Characterization of the Pandemic H1N1/2009 Influenza Virus in Humans Based on Non-Structural Genes. PLoS ONE 2013, 8, e56201. [CrossRef] [PubMed]

134. Garten, R.J.; Davis, C.T.; Russell, C.A.; Shu, B.; Lindstrom, S.; Balish, A.; Sessions, W.M.; Xu, X.; Skepner, E.; Deyde, V.; et al. Antigenic and genetic characteristics of swine-origin 2009 A(H1N1) influenza viruses circulating in humans. Science 2009, 325, 197-201. [CrossRef] [PubMed]

135. Falfán-Valencia, R.; Narayanankutty, A.; Reséndiz-Hernández, J.M.; Pérez-Rubio, G.; Ramírez-Venegas, A.; Nava-Quiroz, K.J.; Bautista-Félix, N.E.; Vargas-Alarcón, G.; Castillejos-López, M.D.; Hernández, A. An increased frequency in HLA class I alleles and haplotypes suggests genetic susceptibility to influenza A (H1N1) 2009 pandemic: A case-control study. J. Immunol. Res. 2018, 2018. [CrossRef]

136. Hertz, T.; Oshansky, C.M.; Roddam, P.L.; DeVincenzo, J.P.; Caniza, M.A.; Jojic, N.; Mallal, S.; Phillips, E.; James, I.; Halloran, M.E.; et al. HLA targeting efficiency correlates with human T-cell response magnitude and with mortality from influenza A infection. Proc. Natl. Acad. Sci. USA 2013, 110, 13492-13497. [CrossRef] [PubMed]

137. Hertz, T.; Nolan, D.; James, I.; John, M.; Gaudieri, S.; Phillips, E.; Huang, J.C.; Riadi, G.; Mallal, S.; Jojic, N. Mapping the Landscape of Host-Pathogen Coevolution: HLA Class I Binding and Its Relationship with Evolutionary Conservation in Human and Viral Proteins. J. Virol. 2010, 85, 1310-1321. [CrossRef]

138. Capittini, C.; Tinelli, C.; Guarene, M.; Pasi, A.; Badulli, C.; Sbarsi, I.; Garlaschelli, F.; Cremaschi, A.L.; Pizzochero, C.; Monti, C.; et al. Possible KIR-driven genetic pressure on the genesis and maintenance of specific HLA-A,B haplotypes as functional genetic blocks. Genes Immun. 2012, 13, 452-457. [CrossRef] [PubMed]

139. La, D.; Czarnecki, C.; El-Gabalawy, H.; Kumar, A.; Meyers, A.F.A.; Bastien, N.; Simonsen, J.N.; Plummer, F.A.; Luo, M. Enrichment of variations in KIR3DL1/s1 and KIR2DL2/L3 among H1N1/09 ICU patients: An exploratory study. PLoS ONE 2011, 6, e29200. [CrossRef]

140. Gonzalez-Galarza, F.F.; McCabe, A.; Santos, E.J.M.D.; Jones, J.; Takeshita, L.; Ortega-Rivera, N.D.; Del Cid-Pavón, G.M.; Ramsbottom, K.; Ghattaoraya, G.; Alfirevic, A.; et al. Allele frequency net database (AFND) 2020 update: Gold-standard data classification, open access genotype data and new query tools. Nucleic Acids Res. 2020, 48, D783-D788. [CrossRef]

141. Robinson, J.; Barker, D.J.; Georgiou, X.; Cooper, M.A.; Flicek, P.; Marsh, S.G.E. IPD-IMGT/HLA Database. Nucleic Acids Res. 2019, 48, D948-D955. [CrossRef]

142. Del Angel-Pablo, A.D.; Juárez-Martín, A.I.; Pérez-Rubio, G.; Ambrocio-Ortiz, E.; López-Flores, L.A.; Camarena, A.E.; FalfánValencia, R. HLA allele and haplotype frequencies in three urban Mexican populations: Genetic diversity for the approach of genomic medicine. Diagnostics 2020, 10, 47. [CrossRef]

143. Liu, J.; Zhang, S.; Tan, S.; Yi, Y.; Wu, B.; Cao, B.; Zhu, F.; Wang, C.; Wang, H.; Qi, J.; et al. Cross-Allele Cytotoxic T Lymphocyte Responses against 2009 Pandemic H1N1 Influenza A Virus among HLA-A24 and HLA-A3 Supertype-Positive Individuals. J. Virol. 2012, 86, 13281-13294. [CrossRef]

144. Dutta, M.; Dutta, P.; Medhi, S.; Borkakoty, B.; Biswas, D. Polymorphism of HLA class I and class II alleles in influenza A(H1N1)pdm09 virus infected population of Assam, Northeast India. J. Med. Virol. 2018, 90, 854-860. [CrossRef]

145. Sun, Y.; Liu, J.; Yang, M.; Gao, F.; Zhou, J.; Kitamura, Y.; Gao, B.; Tien, P.; Shu, Y.; Iwamoto, A.; et al. Identification and structural definition of H5-specific CTL epitopes restricted by HLA-A*0201 derived from the H5N1 subtype of influenza A viruses. J. Gen. Virol. 2009, 91, 919-930. [CrossRef] [PubMed]

146. Corrah, T.W.; Goonetilleke, N.; Kopycinski, J.; Deeks, S.G.; Cohen, M.S.; Borrow, P.; McMichael, A.; Brackenridge, S. Reappraisal of the Relationship between the HIV-1-Protective Single-Nucleotide Polymorphism 35 Kilobases Upstream of the HLA-C Gene and Surface HLA-C Expression. J. Virol. 2011, 85, 3367-3374. [CrossRef] [PubMed]

147. Tong, J.C.; Zhang, Z.H.; August, J.T.; Brusic, V.; Tan, T.W.; Ranganathan, S. In silico characterization of immunogenic epitopes presented by HLA-Cw*0401. Immunome Res. 2007, 3, 7. [CrossRef] [PubMed]

148. Walshe, V.A.; Hattotuwagama, C.K.; Doytchinova, I.A.; Wong, M.; Macdonald, I.K.; Mulder, A.; Claas, F.H.J.; Pellegrino, P.; Turner, J.; Williams, I.; et al. Integrating In Silico and In Vitro Analysis of Peptide Binding Affinity to HLA-Cw*0102: A Bioinformatic Approach to the Prediction of New Epitopes. PLoS ONE 2009, 4, e8095. [CrossRef] [PubMed] 
149. Clemens, E.B.; Grant, E.J.; Wang, Z.; Gras, S.; Tipping, P.; Rossjohn, J.; Miller, A.; Tong, S.Y.C.; Kedzierska, K. Towards identification of immune and genetic correlates of severe influenza disease in Indigenous Australians. Immunol. Cell Biol. 2016, 94, 367-377. [CrossRef]

150. Lester, S.; Cassidy, S.; Humphreys, L.; Bennett, G.; Hurley, C.K.; Boettcher, B.; McCluskey, J. Evolution in HLA-DRB1 and major histocompatibility complex class II haplotypes of Australian aborigines definition of a new DRB1 allele and distribution of DRB 1 gene frequencies. Hum. Immunol. 1995, 42, 154-160. [CrossRef]

151. Ochoa, E.E.; Huda, R.; Scheibel, S.F.; Nichols, J.E.; Mock, D.J.; El-Daher, N.; Domurat, F.M.; Roberts, N.J., Jr. HLA-associated protection of lymphocytes during influenza virus infection. Virol. J. 2020, 17, 1-13. [CrossRef] [PubMed]

152. Ponce-Gallegos, M.A.; Ruiz-Celis, A.; Ambrocio-Ortiz, E.; Pérez-Rubio, G.; Ramírez-Venegas, A.; Bautista-Félix, N.E.; FalfánValencia, R. Polymorphisms in Processing and Antigen Presentation-Related Genes and Their Association with Host Susceptibility to Influenza A/H1N1 2009 Pandemic in a Mexican Mestizo Population. Viruses 2020, 12, 1224. [CrossRef] [PubMed] 